Portland State University

PDXScholar

Spring 7-17-2017

\title{
Patients and Nurses and Doctors Oh My!: Nurse Retention from a Multi-Foci Aggression Perspective
}

Kevin Oliver Novak

Portland State University

Follow this and additional works at: https://pdxscholar.library.pdx.edu/open_access_etds

Part of the Nursing Commons, and the Psychology Commons

Let us know how access to this document benefits you.

\section{Recommended Citation}

Novak, Kevin Oliver, "Patients and Nurses and Doctors Oh My!: Nurse Retention from a Multi-Foci Aggression Perspective" (2017). Dissertations and Theses. Paper 4013.

https://doi.org/10.15760/etd.5897

This Thesis is brought to you for free and open access. It has been accepted for inclusion in Dissertations and Theses by an authorized administrator of PDXScholar. Please contact us if we can make this document more accessible: pdxscholar@pdx.edu. 
Patients and Nurses and Doctors Oh My!: Nurse Retention from a Multi-Foci Aggression

Perspective

by

Kevin Oliver Novak

A thesis submitted in partial fulfillment of the requirements for the degree of

Master of Science

in

Psychology

Thesis Committee:

Leslie Hammer, Chair

Liu-Qin Yang

Donald Truxillo

Portland State University

2017 


\begin{abstract}
Attrition is a serious issue in the nursing industry. One factor influencing rates of attrition in nursing is aggression victimization at work (Estryn-Behar et al., 2010). However, there is little research in the aggression literature that examines how aggression from different sources affects attrition (both job and career turnover) differently. This study attempts to better understand the linkages between aggression victimization and nursing attrition; specifically how aggression from different sources (i.e. patients/patients' families, coworkers, and licensed independent practitioners) differentially affects retention factors (i.e. job satisfaction, turnover intentions, and career commitment). This study also attempts to understand the role that prosocial motivation may have in buffering against negative work attitudes brought about by patient aggression victimization. A two time point cross-sectional survey design was conducted in a hospital organization in the state of Oregon. The data presented here are part of an archival examination of that larger dataset that uses 337 voluntary nursing participants. Findings partially support the idea that different sources of aggression differentially affect retention outcomes like job satisfaction, turnover intentions, and career commitment. Some limitations and contributions of the study are also discussed.
\end{abstract}


Table of Contents

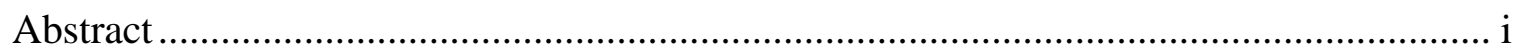

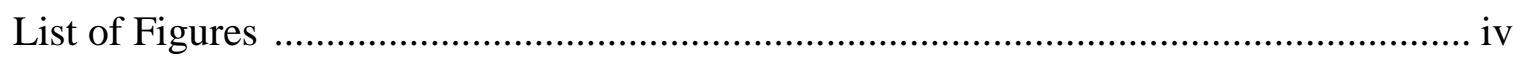

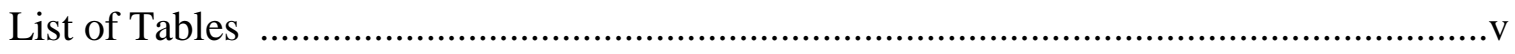

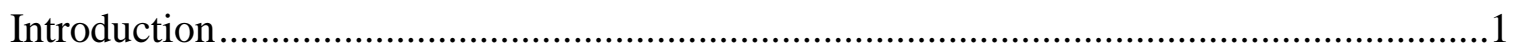

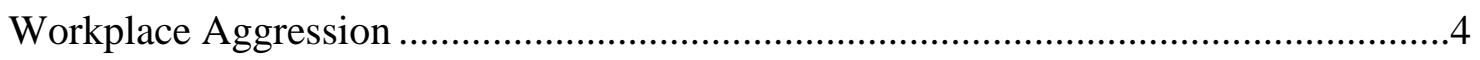

Transactional Stress Model .................................................................................8

Workplace Aggression: The Nomological Network .................................................9

Retention Factors as related to Workplace Aggression and Nursing .........................18

Multi-Foci aggression and the relational model of aggression ................................21

Retention and Multi-Foci Aggression .........................................................27

The Buffering Role of Prosocial Motivation ..........................................................28

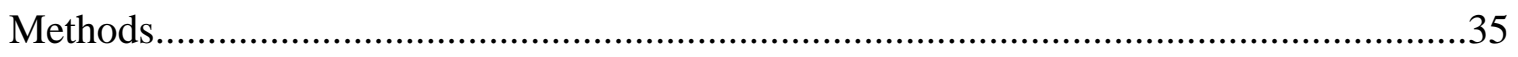

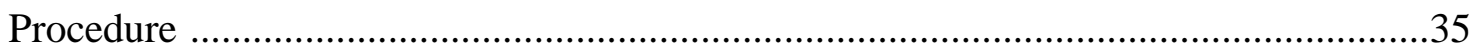

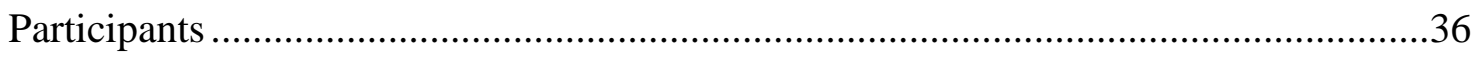

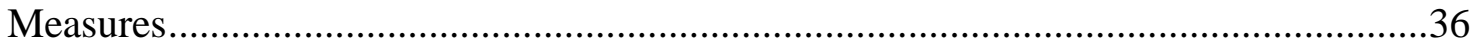

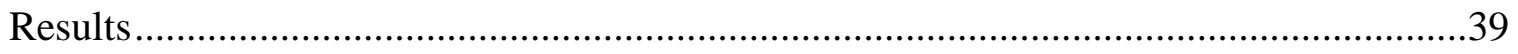

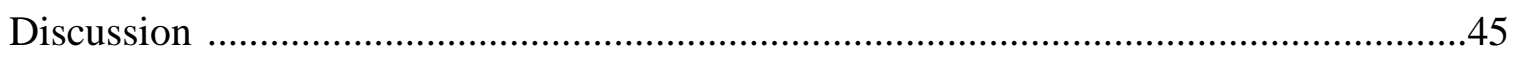

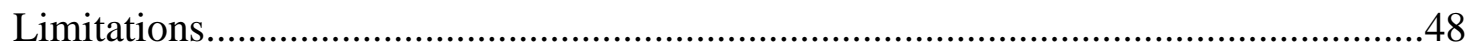




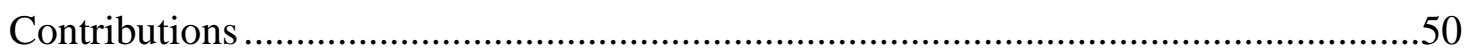

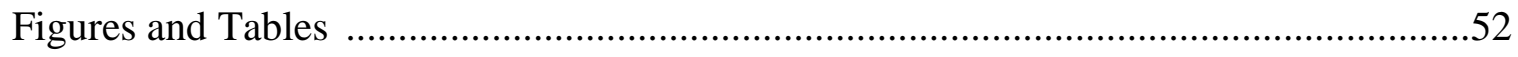

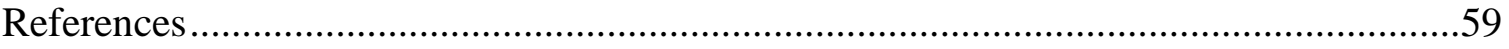

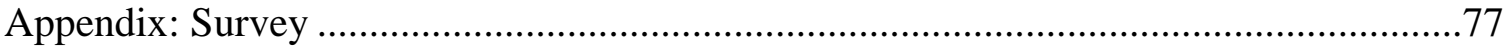




\section{List of Figures}

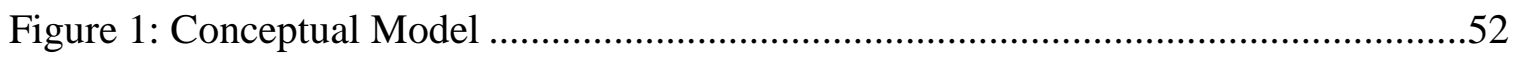

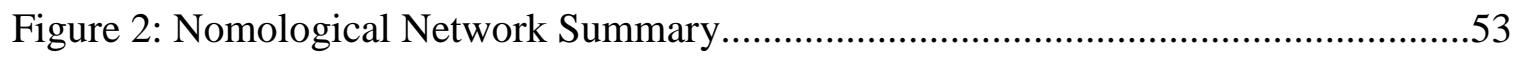




\section{List of Tables}

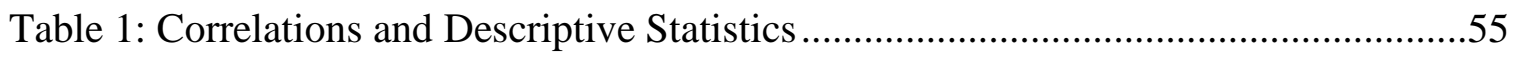

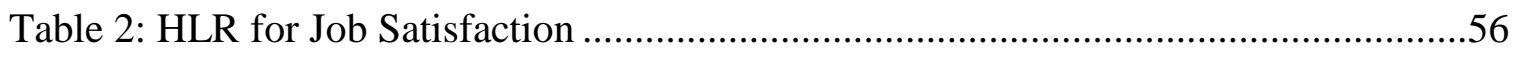

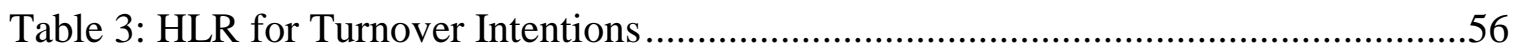

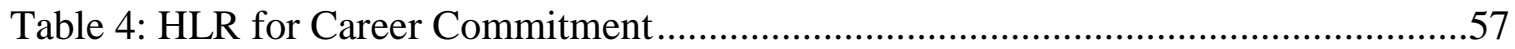

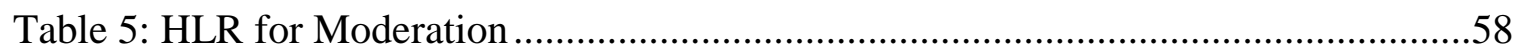




\section{Introduction}

The successful victory in World War II and the prosperous 1950s led to a large influx in birth rates and population growth in the United States, which gave rise to the baby boomer generation (Light, 1988). Considered the children of the greatest generation of Americans, the baby boomers (born between 1946 and 1964) grew up in a thriving

economy, were highly educated, and constituted one of the largest workforce generations in U.S. history (Light, 1988). Now, most of those 75 million baby boomers are reaching retirement age and millions of jobs ar in danger of becoming unfilled, or filled with inexperienced individuals (Dohm, 2000). This encroaching event is known as the silver tsunami (Cruce \& Hillman, 2012), and may result in a large decrease in able-bodied workers, and increased strain on various institutions like social security and healthcare. The silver tsunami is especially relevant to the healthcare industry, where it will not only decrease the worker pool significantly (with many baby boomer nurses retiring), but also create larger strains and demands on the healthcare workers themselves who must care for a larger number of aging baby boomers (Knickman \& Snell, 2002).

In the healthcare industry, the problems that the silver tsunami poses are compounded by the attrition of younger healthcare workers (something this paper will go into detail with). Many younger healthcare workers are lured to the industry by the promises of opportunities, good pay, and a fulfilling career, but few actually understand what jobs in healthcare actually mean. The retiring of countless baby boomers is unavoidable, but we can focus on the workers who will remain in the healthcare industry and ensure that they prosper in the face of incoming work demands. One way to ensure that younger employees can be successful in the face of the incoming workplace 
challenges, is to study what factors influence job and career retention in healthcare workers. When we understand these factors, we can better select, train, and lead the next generation of lifelong healthcare workers.

The first important factor to explore and understand in this story is attrition and why it occurs in this specific industry. Attrition (reduction in staff due to retirement and resignation) is becoming increasingly problematic for the nursing workforce as estimates suggest a 36\% nursing shortage by 2020 (De Gieter, Hofmans \& Pepermans, 2011). This shortage is influenced by the stressful nature of the nursing profession, where job and career turnover is high (Bedeian, Kemery, \& Pizzolatto, 1991; Estryn-Behar et al., 2010). One factor that heavily influences nursing retention is workplace aggression (Aquino \& Thau, 2009; Deery, Walsh, \& Guest, 2011; Hayes et al., 2006). Workplace aggression is an organizational phenomenon that is detrimental to many work outcomes, from individual well-being (Aquino \& Thau, 2009) to intention to leave the organization (Deery, Walsh, \& Guest, 2011) and the profession (Estryn-Behar et al., 2010). It is a phenomenon that is surprisingly common, with one national study estimating that $6 \%$ of respondents reported experiencing physical aggression and $41 \%$ reported experiencing psychological aggression within the prior year (Schat, Frone, \& Kelloway, 2006). Another national study found that between 1993 and 1999, there was an average of 1.7 million reported acts of non-fatal work related violent incidents each year (Durhart, 2001). Estimates from both of these survey studies are also likely conservative, given the nature of under-reporting in working populations, the use of unreliable worker's compensation claim data, and the use of different operations of workplace aggression 
(Dupré \& Barling, 2002; Durhart, 2001). It is evident that workplace aggression remains to be a problem and research has shown that it leads to many negative consequences.

The purpose of this study was to examine how different sources of aggression (i.e. patients and patient's family, coworkers, and licensed independent practitioners) termed "multi-foci aggression" (Chang \& Lyons, 2012) differentially relate to retention factors (i.e., job satisfaction, turnover intention, and career commitment). This study also aimed to understand how trait prosocial motivation may serve as a buffer against job and career withdrawal in hopes of better understanding the relation between workplace aggression and nursing retention factors (see Figure 1 for conceptual model). In this study I focused on nonphysical aggression because of its greater prevalence rate relative to physical aggression, and its generalizability across occupations and industries. There are no studies to the best of my knowledge that report physical aggression at work as having a higher frequency than nonphysical aggression. Most prevalence data show that physical aggression occurs in $1-47 \%$ of survey participants across samples while nonphysical aggression occurs in 39-95\% of survey participants across samples depending on the work setting, levels of under-reporting, the number of years the data was collected, and method of data collection (see Gerberich et al., 2004; Duhart, 2001; Schat, Frone, \& Kelloway, 2006; Einarsen \& Raknes, 1997; O’Connell, Young, Brooks, Hutchings, Lofthouse, 2000; Yang, Spector, Chang, Gallant-Roman, \& Powell, 2012). I focused on the targets' perspectives, since the end goal is to understand aggression exposure and how it relates to nursing retention. 
The three retention factors of interest in this paper include job satisfaction, turnover intention, and career commitment. Job satisfaction is included in the model because it is heavily influenced by affect and relationships at work (Aytaç \& Dursun, 2012; Barclay \& Aquino; Bowling \& Beehr, 2006; Schat \& Kelloway, 2005). Turnover intention is the most proximal predictor of job turnover, which makes it a reliable proxy for objective turnover data (Tett \& Meyer, 1993). Lastly, career commitment is a variable of interest that is related to career continuance and willingness to stay in a profession (Ayree \& Tan, 1992). These three variables are important for illustrating how aggression from various sources contributes to nursing retention.

The purpose of this study is to examine three influences of turnover in nurses (i.e. job satisfaction, turnover intentions, and career commitment) in light of aggression victimization from different sources in the nursing industry. The hope is to find that the different sources of aggression influence turnover differently. In the following sections I will further elaborate on workplace aggression, its relation to retention-related variables, moderators (i.e. aggression source and trait prosocial motivation), and my hypothesis development. I begin by discussing the broader literature surrounding general workplace aggression.

\section{Workplace Aggression}

Definitions. Workplace aggression is defined here as any overt act (whether physical or nonphysical) that harms employees at work (Neuman \& Baron, 2005). Because there are many sub-constructs and phenomena related to workplace aggression 
in the literature (Hershcovis, 2011), it is important to differentiate it from other commonly researched and related factors.

Constructs such as workplace bullying, incivility, violence, abusive supervision and workplace deviance are more specific forms of aggression with different defining characteristics. Workplace bullying is defined as a power motivated process that consists of repetitive harmful behaviors towards a target (Rayner \& Hoel, 1997), which may include repeated sexual harassment, excluding someone from social relationships, verbal attacks, or repetitive threats of violence (Zapf et al., 1996). Incivility is an indirect and subtle form of aggression categorized by ambiguous intent that violates organizational norms for respect (Andersson \& Pearson, 1999). Being rude to someone, demeaning, ignoring, and unwarrantedly dismissing someone's authority or decisions are all examples of workplace incivility (Blau \& Andersson, 2005). Workplace violence is a physical form of workplace aggression characterized by direct physical contact, which can include punching, pushing, and shoving (Baron \& Neuman, 1996). Abusive supervision is a form of workplace aggression that is defined as any supervisor initiated nonphysical aggressive behavior directed towards a subordinate at work (Tepper, 2007). Abusive supervision may include using power oppressively, yelling at a subordinate, or undermining a subordinate (Tepper, 2007). Some literature on abusive supervision will be used in this paper because of its relevance to multi-foci aggression. Finally, workplace deviance is an organization-centric form of aggression defined as any voluntary behavior that directly or indirectly threatens the organization (Bennet \& 
Robinson, 2000). Examples of workplace deviance include theft, sabotage, vandalism, and voluntary absenteeism (Bennet \& Robinson, 2000).

These constructs have some degree of overlap with each other (e.g. a supervisor can bully someone physically), but it is important to understand that they are conceptually related yet different constructs (Tepper \& Henle, 2011). To prevent confusion in this paper, I would like to emphasize that my study focuses on nonphysical aggression at work from the perspective of the target. At times, I may draw upon relevant empirical or theoretical evidence concerning topics such as workplace bullying, abusive supervision because this paper deals with nonphysical aggression from various sources at work (i.e. patients, coworkers, and supervisors). Research in the nursing literature looks at these various sources of aggression and has documented their prevalence.

Aggression prevalence in nursing. As discussed briefly in the beginning of this paper, workplace aggression has become a widespread problem across industries, especially within helping professions like nursing. In fact, aggression in nursing has been documented in many countries as a frequently occurring phenomenon. In the United States, one comprehensive study found that aggression among nurses was a serious issue with most aggressive acts coming from patients (Yang \& Caughlin, 2012). In an aggression prevalence study conducted in the United Kingdom, researchers found that $27 \%$ of healthcare staff were assaulted, and $68 \%$ were verbally abused by patients in the prior year (Winstanley \& Whittington, 2004). Another prevalence study conducted in Iran found that within a 6-month period, $27.6 \%$ of nurses reported experiencing physical 
aggression, and $87.4 \%$ reported experiencing verbal abuse (Shoghi et al., 2008). A study in Taiwan examining the prevalence of aggression towards nurses in a psychiatric hospital found that $35.1 \%$ reported experiencing physical abuse, while $50.9 \%$ reported experiencing nonphysical abuse (Chen et al., 2008).

A review that examined patient initiated aggression found that $25 \%$ of health care professionals experienced physical aggression from patients and visitors, and 50\% experienced verbal aggression from patients and visitors in a year preceding data collection (Hahn et al., 2008). In an aggression prevalence study using a nursing sample, Gerberich and colleagues (2004) found that $13.2 \%$ of participants experienced physical aggression while $38.8 \%$ experienced nonphysical aggression. The same study also found that $96 \%$ of those exposed to physical aggression and $67 \%$ of those exposed to nonphysical aggression reported being the targets of patients (Gerberich et al., 2004).

Other research has shown that aggression from staff is also a problem in nursing. A more recent study conducted among nurses working in various settings (Yang \& Caughlin, 2012) found that $69 \%$ of participants experienced physical aggression from patients and $12 \%$ experienced physical aggression from other staff. Nonphysical aggression was reported as more prevalent, with $89 \%$ of participants having experienced it from patients, and $68 \%$ having experienced it from other staff. The literature all points to workplace aggression as being a serious problem in the healthcare industry and that most of it is patient-source and nonphysical. However, if aggression exposure rates are so high, why are attrition rates not higher? It is possible that people appraise aggression 
differently, depending on who the perpetrator is. This is a form of coping that is discussed in Lazarus and Folkman's transactional stress model.

\section{Transactional Stress Model}

This paper discusses two main theoretical structures: one that deals with how three sources of aggression differentially relate to employee outcomes (multi-source aggression), and another that explains how social orientations (self- versus otherorientations) affect decision making on the job. However, it is necessary to understand the entirety of the presented conceptual model under one larger unifying theory, which I will argue here as Lazarus and Folkman's theory of transactional stress.

Lazarus and Folkman's (1984) theory of transactional stress states that when a person encounters a stressful event they immediately engage in primary appraisal (evaluation of the threat) followed by secondary appraisal (evaluation of coping resources). The reaction to a stressful event is a function of how threatening the event is perceived to be, and how many resources (e.g. social and cultural) are available to the individual (Lazarus \& Folkman, 1984). The theory also differentiates between two forms of coping strategies: problem-focused and emotion-focused coping strategies. Problemfocused coping strategies include individuals making changes to the actual stressor or cognitively reappraising it as more positive, while emotion-focused coping strategies include more emotion-regulation in an effort to mentally detach or escape from the stressor (Aquino \& Thau, 2009).

One study examining cognitive appraisal in aggression found that those individuals who had positive attitudes towards revenge also reported engaging in 
aggression more following aggression exposure (Aquino \& Douglas, 2003). Some studies have also found that quitting or transferring jobs can be a successful problemfocused strategy following aggression exposure (Tepper, 2000; Zapf \& Gross, 2001). In regards to emotion-focused coping strategies, one study found that some employees who have been exposed to customer verbal aggression engage in either surface acting (suppressing emotions or faking) or deep acting (changing beliefs or feelings about something) to cope with the stress (Grandey, 2004).

The transactional stress model is a framework that has been used in stress and aggression research and applies to this study as well. It may be that different sources of aggression trigger different cognitive appraisals within employees, who then react according to those appraisals. We will come back to this discussion in later sections with multi-foci aggression and prosocial motivation. To better understand how relational processes may affect retention differently, it is first important to understand their antecedents and nomological network.

\section{Workplace Aggression: The Nomological Network}

Workplace aggression is a pervasive issue that is related to many workplace factors. Antecedents of workplace aggression include both individual-level and situationlevel factors. Workplace aggression antecedents are important to discuss in this study because it helps us understand what kinds of individuals and situations give rise to aggression in the first place. Once antecedents are established, we can have better insight into why certain sources of aggression may be more prevalent or detrimental for individual outcomes. Individual-level antecedents have been broken down into 
demographic and socio-emotional predictors in the workplace aggression literature (for a review see Barclay \& Aquino, 2011). Situation-level antecedents can be broken down into stressors, environmental characteristics, and relational factors. Outcomes of workplace aggression exposure include individual well-being, behavioral outcomes and attitudinal outcomes. Moderators of workplace aggression exposure are also presented. See figure 2 in the appendix for a summary of the nomological network presented in this paper.

Individual-level antecedents. Individual-level antecedents include any predictors of workplace aggression that stem from the individual. These include demographics and socio-emotional factors presented here. Although behavioral sciences stray away from focusing on individual factors as the sole causal mechanisms for phenomena, they do nonetheless influence workplace aggression exposure.

Demographics. Demographics are important to consider in this study because we have a predominantly female sample with varying degrees of education. These become important to understand in the background so that we can decide on whether we need to control for any of these factors later on or not. One demographic that has been studied in the context of aggression exposure is gender. Aquino and Bradfield (2000) found that from the target's perspective, females perceive being exposed to aggression more often than men. The issue with linking gender to aggression exposure is that it varies greatly depending on what kind of aggression is being studied. While males tend to experience more physical aggression, females experience more sexual harassment (Pimlott-Kubiak \& Cortina, 2003). Having prior history with aggression also has an influence on the 
occurrence of workplace aggression. There is some evidence to suggest that individuals who experienced nonphysical aggression in the past are at a higher risk for experiencing physical workplace aggression in the future (for reviews see Schat, Frone, \& Kelloway, 2006; Barling, Dupre, \& Kelloway, 2009). Another demographic variable found to have an effect on the occurrence of workplace aggression is education. In their study on the risk factors for physical aggression in Taiwanese nurses, Pai and Lee (2011) found that when compared to nurses with vocational schooling or a Master's degrees, nurses with a Bachelor's degree were at higher odds of being exposed to physical aggression.

Socio-emotional factors. Socio-emotional factors are dispositions or states within a person. Socio-emotional factors are important to consider in this study because they might give us a clue in to what kind of individuals are targeted most, and by whom. Trait negative affectivity is one psychosocial state that is linked to aggression exposure. Although findings are not always consistent, some studies have found negative affectivity to be positively related to workplace harassment exposure (Spector \& O’Connell, 1994). Pai and Lee (2011) found that high target anxiety increased the odds of being exposed to verbal abuse. Another interesting socio-emotional predictor of workplace aggression is self-control. A study by Douglas and Martinko (2001) found that self-control (the ability to maintain control over one's emotions) was a significant predictor of workplace aggression initiation, and that along with trait anger, attribution style, negative affectivity, attitudes towards revenge, and previous aggression history accounted for $62 \%$ of variance in participants' self-reports of workplace aggression. Even though this study used the perpetrator's perspective, it is important to understand that whatever factors affect the 
incidence of aggression perpetration, have a direct effect on aggression exposure. Although individual antecedents may have a role in workplace aggression exposure occurrence, situational antecedents tend to be stronger.

Situation-level antecedents. Situation-level antecedents include variables that are associated with the job itself or the organization that an individual is nested within. Situational predictors are broken down here into workplace stressors, environmental characteristics and psychosocial factors.

Workplace stressors. Workplace stressors are situation-level factors that create demands on individuals, causing strains (Spector \& Jex, 1998). Workplace stressors are very important to understand for this study because we may find possible controls to incorporate into the model. Pai and Lee (2011) found that shift work was one significantly important workplace stressor that was related to workplace aggression exposure. Working during the night not only disrupts sleeping patterns, but also makes for higher irritability and susceptibility to aggression. The freedom for employees to dictate how they complete tasks is also important in predicting their aggression exposure. In a study examining the various factors surrounding workplace harassment from the target's perspective, Bowling and Beehr (2006) found that those who had lower job autonomy were more likely to be exposed to workplace harassment. Workload also had an effect on workplace aggression. A study that examined antecedents and consequences of aggression for nurses found that high job demands was linked to more threats of assault from outsiders like patients (Demir \& Rodwell, 2012). 
Environmental characteristics. Environmental characteristics of a job are any factors that are inherent in a job setting. Environmental factors are important to understand because they may be partially responsible for specific sources of aggression, and that may also affect what I control for. Factors such as crowding and high humidity (effects of cost-cutting by organizations) have been linked to increased rates of workplace aggression exposure (Neuman \& Baron, 1998). Safety considerations have also been examined in the literature as possible antecedents of workplace aggression. One study found that the lack of personal protective equipment (PPE) was linked to higher rates of workplace aggression exposure (Farrell, Shafiei \& Chan, 2013).

Psychosocial factors. Lastly, I will discuss psychosocial factors, which seem to be among the best predictors of workplace aggression. There is ample evidence to suggest that workplace aggression exposure is increased in organizations with poor leadership (Barling, Kelloway, \& Frone, 2004; Hershcovis \& Barling, 2006). Poor leadership does not just result in bad management of aggressive incidents, but it also acts as an inadequate conduit for relaying organizational policies and procedures for other employees to follow. Another important psychosocial factor is support. Research suggests that low supervisor support and low coworker support are both linked to perceptions of internal emotional abuse in employees (Demir \& Rodwell, 2012).

Another psychosocial antecedent I will discuss here is violence prevention climate (VPC). Violence prevention climate refers to employees shared perceptions of management's control and elimination of aggression exposure, reflected in the enforcement of policies and procedures aimed at aggression prevention (Spector, Coulter, 
Stockwell, \& Matz, 2007). In their study, Spector and colleagues (2007) found that the level of VPC is negatively related to physical and nonphysical aggression, injury, and perceived danger in employees. A longitudinal study conducted by Yang and colleagues (2012) found that VPC, specifically the pressure against aggression prevention dimensions, was predictive of nurses' exposure to physical aggression (Yang, Spector, Chang, Gallant-Roman, \& Powell, 2012). VPC highlights the importance of the context and leadership responsible for managing aggression at work. A meta-analysis conducted by Yang and colleagues (In press) found that psychological mistreatment climate significantly predicts mistreatment exposure, supporting the idea that climate influences the occurrence of aggression. Apart from contextual factors that affect aggression occurrence directly, there are factors that alter the state of aggression-outcome relationships altogether.

Moderators of workplace aggression. Moderators of workplace aggression are any factors that alter the strength of the aggression exposure-outcome relationship, and are categorized as protective or exacerbating factors. Moderators are categorized here as individual, relational, and organizational.

Individual-level moderators. Individual moderators include self-control and generalized self-efficacy. Taking a perpetrator perspective, self-control in participants was found to protect against workplace deviance following psychological contract breach, such that those with high self-control were less likely to engage in workplace deviance after being exposed to a psychological contract breach (Restubog et al., 2012). Although this study focuses on the target's perspective, factors that affect the initiation of 
aggression directly affect the targets. A study examining the role of negative affectivity and generalized self-efficacy in the bullying-psychological health relationship found that those participants who had higher generalized self-efficacy were better protected against the negative health outcomes resulting from bullying exposure (Mikkelsen \& Einarsen, 2002).

Relational moderators. Social support is an important moderator to consider in any stressor-strain relationship (e.g. aggression and strain). Many studies have found that instrumental and supports buffer against the negative outcomes following aggression exposure (e.g., Schat \& Kelloway, 2003; Schat \& Kelloway, 2005). Another relational moderator particularly important to this study is the relationship between the perpetrator and the target of the aggression. The relative power, task interdependence, and relational connectedness between a perpetrator and target of aggression alter how the target appraises aggressive acts (Hershcovis \& Barling, 2007). This study deals with how nurses appraise aggression differently depending on whether the perpetrator is a patient, coworker, or supervisor. More time will be dedicated later in this paper discussing how the aggression source changes the relation between aggression and retention variables.

Organizational moderators. Organizational moderators are variables that stem from the context of the workplace, and are usually variables that produce a "top-down" effect on individual outcomes. One study examining the role of schoolteachers' perceived organizational support (POS) in the context of bullying found that when teachers had higher (POS), they were less likely to leave the organization following bullying exposure (Djurkovic, McCormack, \& Casimir, 2008). Better control over one's 
job has also been observed as a protective factor. Tepper (2000) found that job mobility acts as a protective factor against abusive supervision's effect on depression and job satisfaction. Resources that buffer against strain caused by aggression can also come in the form of positive climates like violence prevention climate (VPC). Psychosocial safety climates are shared perceptions of policies and procedures surrounding the protection and maintenance of worker psychological health and safety (Law, Dollard, \& Tuckey, 2011). Law and colleagues (2011) found that when (PSC) was strong, the relation between bullying and psychological problems was reduced. These moderators are important for helping practitioners and scientists understand the contingencies under which certain mechanisms might affect outcomes of aggression exposure differently.

Individual-level outcomes of aggression exposure. Individual-level outcomes of aggression exposure are broken down into three main categories: well-being, behavioral and attitudinal outcomes. Well-being factors are those that have to do with physical, mental, and emotional health and are often studied in fields like occupational health psychology. Behavioral outcomes in aggression research include targets' behavioral reactions after aggression exposure, and their task performance. Lastly, attitudinal outcomes deal with how people perceive and think about their workplace after being exposed to aggression. Attitudinal outcomes are especially relevant for this study.

Individual well-being outcomes. Workplace aggression is inextricably linked to poor well-being outcomes. Individual well-being outcomes include any factors that are related to physical, mental, or emotional health. Many studies that examine the outcomes of workplace aggression find that it is strongly related to negative affect and various 
psychological problems such as depression, anxiety, and post-traumatic stress disorder (PTSD) (for a review see Aquino \& Thau, 2009). One study examining individuals who were exposed to aggression found that participants had lower levels of social supports, greater depression and greater anxiety, and greater negative affectivity (Hansen, Hogh, Persson, Karlson, Garde, \& Orbaek, 2006). Physical symptoms are also apparent after aggression exposure. One study using the Minnesota nurses' study found that participants experienced greater chronic pain and muscle tensions following a work related violent incident (Gerberich et al., 2004). It is thus not a surprise that given all the negative health outcomes, employees would be eager to either act out or withdraw from work.

Individual behavioral outcomes. Behavioral outcomes of workplace aggression are behaviors in response to workplace aggression exposure. These behaviors can be either ways of coping with the strain of aggression exposure or withdrawing from the job or situation itself, or on-the-task behavior (task performance). One study that examined the consequences of mistreatment exposure found that those individuals who were exposed showed significantly higher rates of wasting organizational resources, being late, and not coming to work (Boswell, \& Olson-Buchanan, 2004). Another study conducted by Schat and Frone (2011) found that workplace aggression exposure was negatively related with both job performance and contextual performance (e.g. interpersonal treatment; Schat \& Frone, 2011).

Individual attitudinal outcomes. Attitudinal outcomes are individual-level variables that are characterized by people's perceptions about other people, organizations, 
or their specific jobs. Job and life satisfaction have been researched extensively with regard to aggression (for a review see Aquino \& Thau, 2009). A study conducted by Tepper (2000), found that after exposure to abusive supervision, participants were significantly more likely to experience lower life and job satisfaction. A study looking at workplace bullying in nurses also found that when employees were exposed to aggression, they were significantly less satisfied with their jobs and had a higher risk for leaving the organization (Quine, 2001). Worker morale and turnover have also been linked to aggression exposure. In a study on multi-foci aggression, researchers found aggression exposure from clients, coworkers, and supervisors to be indirectly related to job morale and turnover intention (Chang \& Lyons, 2012). Some studies with nursing specific samples have also found that aggression exposure significantly relates to turnover intention and career commitment (Estryn-Behar et al., 2010). Nurses who were exposed to aggression were less likely to be committed to their careers as nurses. Job satisfaction, turnover intention, and career commitment are three attitudinal factors that are highly related to worker retention and require greater attention.

All these variables are important to understand as part of the nomological network and paint a picture of how aggression victimization may be exacerbated by other factors, and vice versa. This is important for interpreting results as we understand that there may be many other factors involved in affecting nurse retention.

\section{Retention Factors as related to Workplace Aggression and Nursing}

Variables such as job satisfaction, turnover intention, and career commitment are all important variables for retention. This study is primarily focused on how aggression 
exposure contributes to retention issues, including ones concerning the retention of nurses in the profession and in the job.

Retention is an important topic to study within the nursing population because of the concern with the nursing shortage and negative impact of turnover on the workload and demands of currently employed nurses (Estryn-Behar et al., 2010). This added stress on the nursing workforce has negative effects on the quality of patient care as well as on the well-being of nurses (Andrews \& Dziegielewski, 2005). Hospitals also suffer financial losses due to poor nursing retention. Jones and Gates (2007) reviewed the nursing retention literature and found that hospitals lose anywhere from $\$ 22,000$ to $\$ 64,000$ per nurse leaving the organization. Understanding what factors may affect nursing retention and how they may affect retention is important to help alleviate this shortage and remove some of the stress from the healthcare industry.

Definitions of retention concepts. In this study I differentiated between joblevel retention and career-level retention. Job-level retention involves employees voluntarily staying in a position within an organization, while career-level retention involves employees voluntarily staying in a given profession. It is possible for an individual to have low job-level retention, but high career-level retention. Given the nursing shortage and nursing career turnover statistics (Estryn-Behar et al., 2010; De Gieter, Hofmans, \& Pepermans, 2011), it is evident that there are elements in the nursing career itself that are causing nurses to leave their jobs and careers. Job satisfaction, turnover intention, and career commitment are like thermometers that can measure the impact that workplace aggression has on the nursing shortage. Job satisfaction is the 
level of which an employee enjoys their job as a whole (Spector, 1997), turnover intention is characterized as employee cognitions surrounding the idea of leaving the organization (Mobley, 1977), and career commitment is defined as an employee's willingness to continue working in a given profession (Blau, 1985).

Turnover intention, job satisfaction and career commitment. The workplace aggression literature has consistently shown that retention suffers as a result of aggression exposure (Mobley, 1977; Barclay \& Aquino, 2009; Estryn-Behar et al., 2010). Research has also pointed to turnover intention as being one retention variable that is highly predictive of employees' turnover. One meta-analysis on turnover found that turnover intention and withdrawal cognitions were among the strongest predictors of turnover, followed by organizational commitment and job satisfaction (Tett \& Meyer, 1993). An empirical study aiming at discovering the precursors to turnover in hospital employees found that it is the intention to quit, and not solely job satisfaction that is the best predictor of the withdrawal process and actual turnover (Mobley, Homer, \& Hollingsworth, 1978).

Job satisfaction is a critical attitudinal variable that can predict an employee's willingness to stay in a job or even profession, however it has not been found to be as stable a predictor of turnover as other indicators (Tett \& Meyer, 1993). This may be due to the fact that the job satisfaction-turnover relationship has many moderators. Another study examining moderators of job satisfaction's effect on turnover found that nurses' attachment to nursing also made the job satisfaction-turnover relationship stronger (Angerami, Gomes, \& Mendes, 2000). Individuals who are attached and committed to 
their careers tend to be affected more by satisfaction with a particular job, since the interest lies in the work or profession itself. One meta-analysis review on the antecedents to retention and turnover among human service employees found that job dissatisfaction and low professional commitment were among the strongest predictors of turnover and intentions to leave (Mor Barak, Nissly, \& Levin, 2001). Thus job satisfaction was relevant to our study of nurses and their retention in the organization and career.

Lastly, career or professional commitment is the retention factor that concerns individuals who stay or leave their professions, and not just their jobs. Research on professional commitment has found that it is significantly related to staying in a given career (Ayree \& Tan, 1992) and less job turnover (Chang, 1999; Zhang et al., 2013). All three of these retention factors are key for understanding the processes via which aggression exposure affects the job and career withdrawal. However, more work is needed to better understand how aggression exposure, specifically multi-foci aggression, affects both the job and the career.

\section{Multi-Foci aggression and the relational model of aggression}

Multi-foci aggression is the study of aggression with an emphasis on how the relationship between the perpetrator and target of aggression changes the process and outcomes of aggression exposure (Chang \& Lyons, 2012; Hershcovis \& Barling, 2007). Multi-foci aggression is an important concept to study, because the phenomenon of workplace aggression is inherently a relational one. Understanding how different perpetrator-target relationships lead to different levels of outcomes is vital for causal inference and intervention work. It is important to study because it helps us understand 
and explain different mechanisms and pathways between aggression and its negative outcomes (Hershcovis et al., 2007). Hershcovis and colleagues (2007) discuss the benefits of operationalizing aggression based on the perpetrator-target relationship between perpetrators and targets of aggression as it provides the groundwork for better measurement, since measuring general aggression can sometimes provide misleading results. It is also important to understand that different sources of aggression may have different predictors and outcomes, which need to be studied interdependently (Hershcovis \& Barling, 2007; Hershcovis et al., 2007, Hershcovis \& Reich, 2013). Building the nomological network of multi-foci aggression helps us to better predict who instigates aggressive incidents and what outcomes follow.

Multi-foci aggression is an important framework to consider so that we can better understand which sources of aggression exposure have a greater impact on the nurses' intentions to stay or leave their job or profession. Through the lens of Lazarus and Folkman's (1984) transactional stress model, it is logical to assume that nurses who experience aggression from different sources, appraise aggression differently based on their relationship with the perpetrator. Some researchers have found that because organizational outsiders are not a permanent factor in their work environment, variables like job satisfaction are less affected by outsider-source aggression than by insider-source aggression (LeBlanc \& Kelloway, 2002). Because of the differential appraisal process, the source of the aggression yields different outcomes for the target. In this study, I focused on how exposure to aggression from organizational outsiders (e.g. patients and their families), coworkers (e.g. other nurses) and licensed independent practitioners (e.g. 
doctors) affect nurses differently. I was particularly interested in further exploring how organizational outsider (patients in this case) aggression exposure affects nurse retention.

Outcomes of organizational outsider aggression. Because a great deal of studies in the workplace aggression literature do not deal directly with patients, I will discuss outcomes of organizational outsiders instead. Consequences of outsider aggression tend to have the greatest effects on emotions and health, which have indirect effects on work outcomes. In a meta-analysis on aggression focusing on source, Hershcovis and Barling (2009) found that outsider aggression was the most detrimental for emotional exhaustion and depression when compared to supervisor and coworker aggression. A study examining the effects of physical or psychological aggression exposure on nurses in an elderly care setting found that nurses who experienced violence from their patients felt feelings of powerlessness, sadness, anger, and feelings of insufficiency (Astrom et al., 2002). Following transactional stress model, it may be that the norm accepts aggression from patients (as opposed to coworkers) and nurses feel they have little control over them, thereby reacting negatively to the aggression exposure. Needham and colleagues (2005) found similar results in their study on the psychological effects of patient aggression on nurses. In their study, they found that patient aggression predicted victim anger, fear, anxiety, post-traumatic stress disorder symptoms, guilt, selfblame, and shame (Needham et al., 2005). Although most research primarily links outsider and patient aggression to poor affective outcomes, these affective consequences are linked to work outcomes such as retention factors of interest to the present study. 
For example, Leiter and Maslach (2009) found that burnout mediated the relationship between nurse's work life and their intentions to turnover. They found that when nurses experienced emotional exhaustion and poor affective states, they were more likely to feel less satisfied with work and more likely to leave the job (Leiter \& Maslach, 2009). Another study also found support for public-initiated physical aggression (physical aggression initiated by an organizational outsider) predicting intent to turnover (LeBlanc \& Kelloway, 2002). The argument for these results was that those individuals who experience physical aggression from organizational outsiders tend to hold occupations where such aggression is part of the job as an occupational hazard. One study examined how supervisor, coworker, and outsider aggression affect employee morale through different pathways. The researchers found that aggression from organizational outsiders predicted higher emotional strain and lower perceived organizational support (Chang \& Lyons, 2012). The path model in this study showed that emotional strain, perceived organizational support, and leader-member exchange all predicted employee morale (i.e. job satisfaction and affective commitment), which in turn predicted turnover intentions. Research is continuing to show that although patient and outsider aggression primarily impacts emotions, these emotions have a negative impact on employee attitudes. While patient aggression may have a more indirect and weaker effects on retention factors, coworker and supervisor aggression have more direct and stronger effects on them.

Outcomes of coworker aggression. Coworker aggression has been found in the literature to negatively relate to workplace outcomes, but is less predictive of these 
outcomes relative to supervisor-initiated aggression. Hershcovis and Barling's (2010) meta-analysis found that exposure to coworker aggression significantly predicted lower job satisfaction, lower affective commitment, greater intent to turnover, and higher levels of depression, but to a lesser extent than exposure to supervisor-initiated aggression did. Another study on different sources of aggression found that compared to public-initiated aggression (e.g. customers, clients, patients) coworker aggression significantly predicted lower emotional and psychosomatic well-being, lower affective commitment, and indirectly predicted intent to turnover (LeBlanc \& Kelloway, 2002).

Other studies found that coworker aggression was predictive of lower perceived organizational support and emotional strain (similar to customer-initiated aggression) and that these factors were predictive of morale and turnover intentions in targeted employees (Chang \& Lyons, 2012; Yang, Caughlin, Novak, Garcia, Do, \& Hoang, 2014). A recent meta-analytical study found that coworker antagonism (e.g., conflict, aggression) significantly predicts two forms of work attitudes (i.e. job satisfaction and organizational commitment), and two forms of withdrawal (i.e. intention to quit and turnover) (Chiaburu \& Harrison, 2008). The authors discuss how coworkers form the basis for how an individual perceives the workplace and their place in it, thereby influencing employee's perceptions of their attitudes, and behaviors. However, since the supervisor has more control and power over what goes on in the workplace, exposure to supervisor aggression tends to predict negative outcomes more strongly than exposure to coworker aggression (Hershcovis \& Barling, 2009). From the perspective of the transactional stress model, when employees appraise their resources are threatened by someone who holds power 
over them (and subsequently withholds resources from the employee), they may be less likely to cope effectively, which could then result in the employee leaving the organization. In the case of supervisor aggression, nurses may feel even more threatened.

Outcomes of supervisor-initiated aggression. Supervisor-initiated aggression has been shown in the research to be the most detrimental (yet less frequent) form of aggression for work outcomes. Because of the power and control that supervisors hold, targets of supervisor-aggression tend to feel as if they have less control over the situation and are unable to formulate any problem-focused strategies to cope with them (Lazarus \& Folkman, 1984; Hershcovis \& Barling, 2007). The meta-analysis conducted by Hershcovis and Barling (2010) on multi-foci aggression found that exposure to supervisor aggression significantly predicted job satisfaction, affective commitment, intent to turnover, psychological and physical well-being, and organizational deviance. Exposure to supervisor aggression was also found to predict all these factors but physical well-being more strongly than coworker aggression (Hershcovis \& Barling, 2010).

Tying this discussion back to the transactional stress model, it seems that people appraise aggression exposure differently partially due to the relative power between themselves and their perpetrator. One study that examined abusive supervision using the transactional stress model found that emotion-regulation strategies (re-appraising ones situation as less threatening) buffered the abusive supervision-outcome relationship (Chi \& Liang, 2012). This study found that abusive supervision had the largest effect on emotional exhaustion and withdrawal factors when subordinates had greater expressive suppression and lower cognitive reappraisal (poorer emotion-regulation strategies). This 
research supports the idea that aggression impacts retention, but the literature has yet to fully explore the role of aggression source on various retention factors. The present study directly compares effect sizes across sources, which will be informative for future research looking at multi-foci aggression and retention factors.

\section{Retention and Multi-Foci Aggression}

All three main sources of aggression (i.e. patient, coworker, and supervisor) relate to retention factors to some extent (see Barclay \& Aquino, 2011; Hershcovis \& Barling, 2009; Chang \& Lyons, 2012). As discussed earlier, it seems that supervisor-initiated aggression tends to have the most powerful and direct effect on certain retention factors like job satisfaction, organizational commitment, while outsider aggression has the weakest effect of the three sources discussed. Based on past research on multi-foci aggression, this study examined whether the strength of the relations between aggression exposure and retention outcomes varies across the three sources of aggression. Since this study used a one-time point within-subjects design, all participants had the opportunity to report aggression exposure from all three main sources (i.e. LIPs, coworkers, and patients). I hypothesized that:

Hypothesis 1a: LIP (supervisor) aggression is more predictive of job satisfaction than exposure to coworker and patient aggression.

Hypothesis 1b: LIP (supervisor) aggression is more predictive of turnover intentions than exposure to coworker and patient aggression. 
Regarding career commitment, it is important to consider the nursing field specifically and how it may operate differently than other occupations. As discussed

previously, patient aggression is perceived to be an occupational hazard and one that is less controllable than other sources of aggression in nursing (LeBlanc \& Kelloway, 2002). Patient aggression is also one of the most frequent occurring forms of aggression in nursing (Yang \& Caughlin, 2012; Gerberich, 2004) and may have a stronger cumulative effect on nurses' careers than coworker or supervisor aggression (De Gieter, Hofmans, \& Pepermans, 2011). Following the transactional stress model, when nurses have difficulty dealing with patient aggression and lack the necessary coping resources to deal with it, they may appraise their situation as threatening or uncontrollable and engage in withdrawal behaviors and lower career commitment (Estryn-Behar et al., 2010; De Gieter, Hofmans, \& Pepermans, 2011). Following the nursing retention research, I hypothesized that:

Hypothesis 1c: Exposure to patient aggression predicts career commitment to a greater extent than exposure to supervisor and coworker aggression.

\section{The Buffering Role of Prosocial Motivation}

Since patient aggression is common and has been shown to be harmful to nurses in many ways, it is important to examine factors that may buffer against the effects of this common form of aggression. In this section I will discuss the possibility of prosocial motivation as a possible buffer against negative outcomes influenced by exposure to patient aggression. I will first discuss the framework of self vs. other orientation and explain its relevance to helping behavior and prosocial motivation. I will also discuss 
how prosocial motivation may increase nurses' resiliency in the face of patient-initiated aggression. Further, prosocial motivation (like other-orientation) is relevant because the work that nurses do is inherently prosocial (e.g. healing the sick) and understanding its role in the appraisal process is important.

Other- vs. self-orientation. Self-orientation is a tendency to make decisions that have a preference for alternatives that satisfy self-interests (Meglino \& Korsgaard, 2007). The opposite disposition is called other-orientation or other-concern. Concern for others in organizations is a relatively new concept that explains how helping behaviors within organizations have positive effects for both employees and organizations. Otherorientation is described as a general concern for the welfare of others (Meglino \& Korsgaard, 2007). Meglino and Korsgaard (2004) first proposed a model with five propositions on the role of other-orientation in organizations. The authors stated that most organizational theories and conceptual models are built on the premise that employees are self-concerned, and that those individuals who are more other-concerned may not operate within that same framework. Below I describe three of their propositions that were relevant to the present study.

The first proposition is that other-orientation may act as a moderator and people who are high in other-orientation may not act the same as "rationally self-interested" do. Other-oriented individuals may perceive, or appraise their surroundings and social relationships differently than self-interested individuals, which result in different work processes and outcomes. The second proposition states that individuals with higher otherconcern are less likely to attempt to fix a failing situation to improve their own standing. 
In other words, other-concerned individuals do not need to succeed in their tasks at all times since they put more value into relationships and are not as easily affected by failures to attain status within an organization. It may be that because they are not selffocused that they are more resilient in the face of adversity at work. The third proposition is very important for this study, as it states that job satisfaction is less affected by job attributes (e.g. skill variety, task significance, autonomy) for those with higher other-concern. This means that those that are higher in other-concern value the job for the helping aspect, and can better cope with jobs that may be more demanding or contain negative job attributes (e.g. repetitive tasks, low autonomy). This proposition is relevant to this study because it can explain why nurses with stronger other-orientations may be better able to deal with more stress in a field like nursing.

Korsgaard, Meglino, and Lester (1996) first tested the theory of other-orientation in organizations and found that individuals that were high in other-concern found personal gains less attractive, and less sensitive to the increases in personal payoff and winning. This study further attempted to show that those higher in other-concern are better able to focus on helping others, and are not as easily affected by negative or positive arousal.

In line with the aforementioned propositions, an empirical study conducted by Meglino and Korsgaard (2007) found that those that held higher other-orientations tended to have fewer negative reactions to job characteristics. The results of the study showed that perceived job attributes (e.g. autonomy) had less of an affect on job satisfaction when the individual was higher in other-orientation. Although the works of Meglino and 
Korsgaard heavily revolve around the theory of other-orientation and how it moderates various work relationships, another series of authors refined and developed the theory further.

In De Dreu's (2006) theoretical paper, the author explains that other-orientation and self-concern have been examined as polar opposite dispositions (one is either strong in one or the other), when in fact these orientations are orthogonal and unipolar. The paper discusses in detail how these two orientations act as moderators for processes in the workplace and that they are domain specific. They explain that self-concern moderates the effects of self-related variables such as job characteristics, while other-concern moderates the effects of social-related variables such as team climate on outcomes such as job satisfaction, motivation, and helping (De Dreu, 2006). An empirical study conducted by De Dreu and Nauta (2009) found that self-concern moderates relationships at the individual level (e.g. job characteristics relate to task performance) while otherconcern moderates relationships at the social and group level (e.g. perceived justice climate relates to prosocial behavior). Knowing this, one can expect that when dealing with relational issues like aggression, that other-orientation will be more relevant to the present study.

An empirical article examining the effects of different orientations as coping mechanisms found that those with higher other-orientations reacted to unfair events through forgiveness, while those with higher self-concern reacted to those events with revenge (Bobocel, 2013). This supports what was discussed earlier with regard to otherorientated individuals being less affected by negative events, and this may also relate to 
how nurses react to patient aggression. Since nurses view patients as sick and in need of help they are more willing to forgive the patients for aggressing. This other-orientation may allow for more effective emotion-regulation by reevaluating situations through a less self-focused lens.

As discussed above, other-orientation seems to play a vital role in relational and social processes, and prosocial motivation is one way to operationalize other-orientation.

Prosocial motivation. Prosocial motivation is defined as the expenditure of effort or resources with the aim of helping another (Batson, 1987). Prosocial motivation can be defined as both a trait and a state, but for the sake of this study we will be focusing on prosocial motivation as a trait. Prosocial motivation as a personality trait is similar to the Big five trait agreeableness and is a general tendency towards being empathic and helpful towards others (Grant, 2008). This tendency seems to be heightened in individuals who hold jobs that care for others (e.g. nursing and social work).

Prosocial motivation may act as a buffer against the negative outcomes of negative relational experiences such as aggression exposure. One empirical study found that under high ambiguity situations, proactivity was higher in those that had more prosocial versus security values (Grant \& Rothbard, 2013). These results indicate that those that are more concerned about their own security (e.g. restraining a violent patient) are less likely to be proactive during ambiguous situations (e.g., patient-initiated aggression) than those who are more prosocially oriented. Prosocial motivation in this case buffers against some of the negative effects on proactive coping brought upon by aggression exposure. 
Prosocial motivation may act as a resiliency trait that supplies an employee with coping strategies in the form of cognitive reevaluation (Lazarus \& Folkman, 1984). Grant and Sonnentag's (2010) empirical study on prosocial impact and negative work factors found that those individuals who perceived prosocial impact were able to compensate for negative work factors such as emotional exhaustion by directing their attention away from themselves and onto others (Grant \& Sonnentag, 2010). Although different constructs, prosocial impact (the feeling that your actions helped someone) and prosocial motivation (the desire to help others) are inextricably linked (Grant \& Sonnentag, 2010; Grant 2007). This means that by focusing on others, employees are able to disregard negative events in their work life or even see them in a different light. Another very recent empirical article found that nurses who had higher prosocial motivation were better able to protect themselves from burnout caused by stress (Hickey, 2013). Consistent with the evidence described above, the present study posits that prosocial motivation can act as a coping mechanism by which individuals evaluate negative events differently than those with lower prosocial motivation.

Specifically, I will be focusing on how trait prosocial motivation can buffer against the potential negative impacts that patient aggression alone has on nursing retention. It may also be that those nurses with lower levels of trait prosocial motivation are unable to cope or deal with patient aggression, and they may be more intent on leaving the job and the profession. As was discussed earlier, patients are seen as a work hazard in the nursing field, so the inability to cope with such a common hazard may push nurses to leave the profession. Nurses with higher prosocial motivation (a more "other- 
oriented" tendency) may be more understanding of patients' plights and appraise aggression from patients as more acceptable, thus being less susceptible to the consequences of aggression exposure. In light of the literature on other- versus selforientation and prosocial motivation, I hypothesized that:

Hypothesis 2: Nurses' trait prosocial motivation level moderates the relation between exposure to patient aggression and career commitment, such that the relation between aggression exposure and career commitment will be weaker for those with higher trait prosocial motivation.

Reevaluating situations and understanding them as being products of the situation (e.g. coworkers are aggressive because they are stressed) rather than products of dispositions (e.g. coworkers are aggressive because they are angry people) may be a product of having an other-orientation and prosocial motivation may be an indicator of such an orientation style. Nurses who are higher in prosocial motivation may be less affected by negative interactions with others. 


\section{Methods}

\section{Procedure}

This study is a cross-sectional study examining the issue of workplace aggression. A healthcare organization in the United States was contacted by a research team from Portland State University and agreed to collaborate on an aggression prevention study. The organization began advertising the study to its healthcare workers via a marketing communications department, which worked closely with the Portland State University (PSU) team. Fliers and e-mails were sent out to all facilities in the organization in hopes of gaining visibility for the study. Electronic surveys were developed on a secure Portland State University account operated through Qualtrics.com. Hardcopy and electronic surveys were developed at the same time and were identical with regard to questions. Hardcopies were mailed to nursing educators who distributed them to nurses, and the links to electronic surveys were given via e-mailing lists. Participants had the opportunity to volunteer to participate within a six-week window. Nurses were not given incentives for taking the survey, however the hospital organization allowed the nurses paid time for taking them during work hours. Surveys were estimated to take participants 20-25 minutes.

After going through the formal consent procedure, nurses were taken to the online survey and allowed to take as much time as they needed to complete it. Participants who completed the survey were presented with a certificate that they could print and present to their supervisors as proof that they completed the survey. For the hardcopy survey, nurses were given an envelope that contained instructions on what needed to be filled out and 
where it needed to be sent back to, two consent forms, and the hardcopy survey itself. The nurses were told to fill out both consent forms, and send one back to the PSU team. Nurses were also told to send the completed hardcopy survey back to PSU via a pre-paid and pre-addressed envelope. Hardcopy surveys were inputted manually into excel, and then reorganized and merged with the qualtrics data.

\section{Participants}

This study used an archival sample of 337 nurses who volunteered in a healthcare organization located in Oregon. The nurses in this study worked an average of 34 hours a week. Nurses were asked by a hospital organization to take the survey on computers or in hardcopy format. Nurses could choose to not take the survey, but were reimbursed by the hospital for taking time to take it. Nurses that wanted a hardcopy survey asked their supervisors, who then relayed the message to our research team at PSU, so that we could ship hardcopy surveys to the work site. The organization consists of eight acute care facilities, each with its own unique number of units. The average age of the sample was 43 years old (see Table 1). Participants volunteered for the study by both signing a consent form and filling out a hardcopy survey, or by agreeing to the electronic consent form and filling out the survey through Qualtrics.com (a professional online surveying platform).

\section{Measures}

Psychological aggression from different sources. These factors were assessed using a five-item psychological aggression measure adapted from the Chang and Lyons (2012) study. Example questions from this measure include "How often have you been 
glared at by (patients/coworkers/LIPs) in the past six months?" and "How often have you been yelled at by (patients/coworkers/LIPs) in the past six months?". Questions were adapted to refer to a specific source (i.e. patient and patient's families, coworkers, or LIPs) so that each category had a set of five psychological aggression questions. Responses to all items in this scale were rated on a 6-point Likert scale $(1=$ Never, $2=$ Once or Twice, 3 = Afew Times, $4=$ Monthly, $5=$ Weekly, $6=$ Daily).

Prosocial motivation. This factor was assessed using a four-item prosocial motivation scale that was adapted from an existing scales (Grant, 2008). First an introductory sentence was asked "Why are you motivated to do your work?". Sample questions following the first question included "Because I care about benefiting others through my work" and "Because I want to have a positive impact on others." Responses to all items in this scale were rated on a 7 -point Likert scale $(1=$ disagree strongly, $7=$ agree strongly).

Job satisfaction. This factor was assessed using the three-item job satisfaction scale taken from the Michigan Organizational Assessment Questionnaire (Cammann, Fichman, Jenkins, \& Klesh, 1979). An example question from this scale is "In general, I like working here." Responses to all items in this scale are answered on a 7-point Likert scale $(1$ = Strongly Disagree, 7 = Strongly Agree $)$.

Turnover intentions. This factor was assessed using the three-item turnover intentions scale adopted from the Michigan Organizational Assessment Questionnaire (Cammann et al., 1979; Yang, Che, \& Spector, 2008). An example question from this 
scale is "I often think of leaving this organization." All items used in this scale were answered on a 7-point Likert scale ( 1 = Strongly Disagree, $7=$ Strongly Agree $)$.

Career commitment. A four-item scale was used to measure career commitment (Blau, 1989). Some sample questions included "If I could go into a different industry other than nursing which paid the same I would probably do so" and "I definitely want a career for myself in nursing". Items were rated on a five-point Likert scale $(1=$ strongly disagree, 5 = strongly agree).

Control variables: Single item measures regarding age, unit tenure, organizational tenure, and weekly hours worked were also measured. Age was chosen as an important control variable because it has been found to be related to workplace outcomes in nurses including staying in the profession (Estryn-Behar et al., 2010). Unit tenure was controlled for as well since it could be related to being a new nurse and having a harder time with social relationships with coworkers and supervisors. Organizational tenure as also controlled for because it indirectly represents being under a certain management with specific policies, and it has been shown to relate to nurses' moving between jobs (Estryn-Behar et al., 2010). Lastly, hours worked per week was also controlled for because it had been shown in the past to relate to workplace outcomes like job satisfaction and turnover, due to unsatisfactory scheduling and work load (Bedeian, Kemery, \& Pizzolatto, 1991). It could also be confounding aggression incidents, since nurses working more hours also might experience more aggression victimization. 


\section{Results}

Due to the relatively low sample size for a moderation model, I ran a post-hoc power analysis G*Power software (Faul, Erdfelder, Lang, \& Buchner, 2007) to assess the likelihood of committing a type II error and failing to reject a false null hypothesis (Tabachnick \& Fidell, 2013). For this study, I used this effect size to estimate power at the $=.05$ level with a sample size of 337 and 8 total predictors. Results from the power analysis showed an estimated power of .43 , which is below the .80 (Tabachnick \& Fidell, 2013). However research has shown that aggression sources do indeed predict retention factors differently (Hershcovis \& Barling, 2010).

IBM SPSS 20 was used for the entire analysis. A descriptives analysis found that all multi-item measures used in the study had adequate Cronbach Alpha scores, ranging from .85 to .97 (see Table 1). Although I expected unit-level nesting to occur, the calculated ICC(1) values for job satisfaction (.03), turnover intentions (.09), and career commitment (.06), did not meet the .1 cutoff point for variance explained due to nesting, thus multi-level modeling was not necessary for this study (Bliese, 2000). While some of these ICC(1) scores were close to the cutoff (i.e. turnover intentions and career commitment), many units had only a few participants and would not have allowed for a fully represented sample. I ignored assessing the facility-level ICC(1) due to nonsignificant nesting found in previous analyses in the same dataset (Yang et al., 2014). Correlation analysis found several initial relationships. Patient aggression was significantly correlated with coworker aggression $(r=.22)$, licensed independent practitioner aggression $(r=.29)$, age $(r=-.15)$, job satisfaction $(r=-.17)$, turnover 
intentions $(r=.20)$, career commitment $(r=-.13)$, and prosocial motivation $(r=-.11)$ to the .05 significance level. Coworker aggression was also significantly correlated with job satisfaction $(r=-.31)$, and turnover intentions $(r=.35)$ to the .05 significance level, but coworker aggression was not significantly correlated with career commitment $(r=-.08)$, or prosocial motivation ( $r=-.03$ ). Lastly, LIP aggression was significantly related to job satisfaction ( $r=-.33)$, turnover intentions $(r=.29)$, career commitment $(r=-.13)$, and prosocial motivation $(r=-.13)$ to the .05 significance level. For all correlations, Cronbach alphas, and descriptive statistics please refer to Table 1 .

For each hypothesis I conducted a four-step hierarchical linear regression by first inputting the control variables (i.e., age, unit tenure, organizational tenure, and hours worked per week) followed by each of the three source-specific predictors (i.e. patientsource aggression, coworker-source aggression, and LIP-source aggression). All variables were centered to reduce the biasing effect of multi-collinearity on focal coefficients (Cohen et al., 2003). I also conducted Johnson's (2000) relative weights analysis for each hierarchical linear regression to address any issues of multicollinearity due to the moderate-level correlations between the three sources of aggression exposure. Johnson's (2000) relative weights analysis creates new predictors that are maximally related to the original predictors, but orthogonal to each other, allowing for the best estimates of correlated independent variables' contribution to R-square for each dependent variable.

Three hierarchical linear regressions were conducted for Hypothesis 1 (for the dependent variables of job satisfaction, turnover intentions, and career commitment). For 
Hypothesis 1a (see Table 2), the hierarchical linear regression revealed that the control variables did not contribute significantly to the regression model, $F(4,317)=1.61, p=$ .17 , and accounted for $2 \%$ of the variation in job satisfaction. Introducing LIP aggression into the model explained an additional $11 \%$ of variation in job satisfaction, and this change was statistically significant, $F(5,316)=9.57, p<.05$. Adding coworker aggression into this model explained an additional $3 \%$ of variance in job satisfaction, and this change was also statistically significant, $F(6,315)=10.25, p<.05$. Lastly, adding patient aggression to the equation did not result in an increase in variance explained, $F(7$, $314)=8.92, p=.33$, and only increased variance explained by $0.3 \%$. For job satisfaction, LIP and coworker aggression explained the most unique variance. Coworker aggression had the largest standardized beta weight in predicting job satisfaction, $\beta=-.213, t(322)=$ $-3.39, p<.05$, followed by LIP aggression, $\beta=-.204, t(322)=-3.18, p<.05$, with patient aggression not significantly predicting job satisfaction, $\beta=-.055, t(322)=-.98, p=.33$. A relative weights analysis showed that the hierarchical linear regression was accurate in its estimates, with LIP aggression accounting for $6.3 \%$ of the total R-square, coworker aggression accounting for $5.7 \%$, and patient aggression accounting for $1.3 \%$. This partially supports hypothesis 1a for job satisfaction. While LIP aggression was not the best predictor of job satisfaction, it was nearly tied with coworker aggression, and a stronger predictor of job satisfaction than patient aggression.

For Hypothesis $1 \mathrm{~b}$ (see Table 3), the controls did not contribute significantly to the variance explained, $F(4,316)=1.81, p=.13$, and only explained $1 \%$ of the variance of turnover intentions in nurses. Adding LIP aggression contributed significantly to the 
variance explained, $F(5,315)=7.44, p<.05$, and explained an additional $8 \%$ of the variance of turnover intentions. Coworker aggression also significantly contributed to the model, $F(6,314)=10.558, p<.05$, and explained an additional $6 \%$ of the variance above and beyond LIP aggression. Patient aggression did not contribute a significant amount of unique variance, $F(7,313)=9.5, p=.09$, and only contributed an additional $.7 \%$ explained variance to turnover intentions. Once again, coworker aggression was the best predictor of the dependent variable (turnover intentions), $\beta=.296, t(321)=4.732, p$ $<.05$, while LIP aggression, $\beta=.101, t(321)=1.58, p=.11$, and patient aggression, $\beta=$ $.10, t(321)=1.68, p=.09$, where not significant predictors of turnover intentions. A relative weights analysis supported these estimates, with coworker aggression accounting for $8.3 \%$, LIP aggression accounting for $4.1 \%$, and patient aggression accounting for $2.2 \%$ of the total R-square. This partially supports hypothesis $1 \mathrm{~b}$ for turnover intentions. The hierarchical linear regression for hypothesis 1c (see Table 4) found that the controls did not significantly contribute to the explained variance of career commitment, $F(4,327)=2.39, p=.051$, and accounted for $1.7 \%$ of variance explained in career commitment. Patient aggression contributed a significant amount of variance to career commitment, $F(5,326)=3.2, p<.05$, and accounted for $3.2 \%$ of variance explained in career commitment. Coworker aggression did not contributed significantly to the variance explained above and beyond patient aggression, $F(6,325)=2.91, p=.23$, and accounted for $3.3 \%$ of variance explained in career commitment. Lastly, LIP aggression also did not contribute significantly, $F(7,324)=2.78, p=.16$, with $3.6 \%$ of the variance explained in career commitment. With all predictors inputted, only patient aggression 
was close to significantly predictive of career commitment, $\beta=-.104, t(332)=-1.75, p=$ .08 , and coworker aggression, $\beta=-.02, t(332)=-.31, p=.75$, and LIP aggression, $\beta=-$ $.09, t(332)=-1.4, p=.163$ were not significant predictors. A relative weights analysis supported these estimates as well, with all three source aggression predictors contributing around $1 \%$ of the total R-square, with patient aggression having a slightly higher contribution of $1.2 \%$. These results partially support hypothesis $1 \mathrm{c}$, since patient aggression is approaching significance and has a higher beta weight than the other two sources of aggression when predicting career commitment.

For Hypothesis 2, I created an interaction term for "patient aggression x prosocial motivation" to assess whether prosocial motivation may buffer against low levels of career commitment in nurses who were exposed to patient aggression. The hierarchical linear regression (see Table 5) found that the controls did not contribute a significant amount of explained variance in career commitment, $F(4,317)=2.17, p=.07$, and accounted for $1.4 \%$ of the variance explained in career commitment when they were entered in step 1. Patient aggression and prosocial motivation contributed a significant amount of variance explained toward career commitment, $F(6,315)=6.05, p<.05$, and accounted for $8.6 \%$ of the variance explained. Lastly, the interaction term of patient aggression $\mathrm{x}$ prosocial motivation did not contribute a significant amount of variance explained into the mode, $F(7,314)=5.2, p=.66$, and only accounted for an additional $.1 \%$ of the variance in the model. The relative weights analysis supported these results as well, with prosocial motivation contributing $6.5 \%$, patient aggression contributing $1.5 \%$, and the interaction term contributing $0.2 \%$ of the total R-square. Hypothesis 2 was 
unsupported, as prosocial motivation did not act as a buffer against patient aggression for career commitment. Prosocial motivation however, was a significant and interest predictor in this case. 


\section{Discussion}

The purpose of this study was to assess how different sources of aggression differentially affect nurse retention outcomes. Hypothesis 1a, which stated that LIP aggression would be a better predictor of job satisfaction than both coworker and patient aggression, was only partially supported. LIP aggression had slightly less but almost the same predictive value as coworker aggression for job satisfaction, and they were both better predictors than patient aggression. This supports the idea that exposure to workspecific sources of aggression affect work-specific outcomes like job satisfaction. Since the aggression is coming from a job-specific setting, a nurse may be more likely to want to leave that specific job, but still remain a nurse. With regard to patient aggression, nurses may tolerate it more because they have come to expect it as part of the job. Nurses may make excuses for violent patient behavior because they are sympathetic towards the patients' pain and suffering. With regard to the issue of coworker aggression being a better predictor for job satisfaction, it may be that there truly is a qualitative difference between doctors as supervisors, and traditional supervisors in other industries where leaders have been shown to be the most influential players in worker outcomes (Hershcovis \& Barling, 2009). Since doctors play more of a role as a care giver than as a direct supervisor, they may not be as influential in nursing outcomes as this author believed.

Hypothesis $1 \mathrm{~b}$ expected LIP aggression to also be a better predictor of turnover intentions than coworker and patient aggression. However, this hypothesis was only partly supported. While patient aggression was still the worst predictor, supporting the 
argument that patient aggression is considered as part of the job, coworker aggression was actually the best predictor of turnover intentions. This may be due to the fact that coworkers are often the primary source of peer support in a workplace (Hershcovis \& Barling, 2009). If a conflict arises between coworkers, a nurse might be far more likely to actually leave the job since he or she may not feel they have a supportive work environment. LIP aggression may not have been a big predictor here because while LIPs hold more power over nurses than coworkers, nurses also have fewer interactions with LIPs and may depend on coworkers for social support in times of victimization from LIPs and/or patients. This relates to the results summary for H1A, where I mentioned that doctors as supervisors may be qualitatively different from supervisors in other industries.

Hypothesis 1c was partially supported, since although none of the source aggression variables were significant predictors of career commitment, patient aggression was approaching significance and had a higher beta than the others. This result compliments the findings from the other two hypotheses, in that it supports the idea that patient aggression (being from organizational outsider and a constant in the industry) can affect a nurse's career commitment (Bedeian, Kemery, \& Pizzolatto, 1991). It may be that when a nurse realizes that her patients can be very aggressive, and that this is pervasive in the entire industry, that she may not want to continue working in that industry. The other side of this coin is that LIP and coworker aggression may simply be a symptom of bad job fit, and a nurse may experience these kinds of workplace aggressions, but still be committed to the career of nursing as a whole. 
Lastly, Hypothesis 2 was unsupported since prosocial motivation was not found to be a significant moderator of patient aggression's effect on career commitment. It may be that prosocial motivation may be too general of a trait to directly affect one's perception of patient aggression, or that nurses get desensitized to the plight of patients as they get older. Another very plausible explanation, is that prosocial motivation may not be the right construct to look at in this context. Prosocial motivation means that someone is driven to help others, but motivation on its own does not necessarily create positive outcomes for employees (De Dreu, \& Nauta, 2009). It may be that prosocial impact, the actual perception that one's actions were helpful and meaningful, is a more fitting construct to look at in this study (Grant \& Sonnentag, 2010). When a nurse sees that his or her actions are benefitting someone, it may create immediate emotional and mental benefits for them. In other words, prosocial motivation may be an indirect way of measuring a nurses helping behavior, while prosocial impact is a more direct and proximal variable that would have more direct links to positive work outcomes. It is advisable for future research to measure prosocial impact as well as other coping mechanisms, such as perspective taking, to better understand the process underlying aggression exposure and retention variables.

In summary, most of the main effect hypotheses were partially supported, and showed there were differences in how aggression victimization affected retention outcomes, even with relevant control variables. The results behind hypothesis 1a-c especially, are important because they do support the idea that the sources of aggression may each affect retention factors in different ways. It is especially important from a 
practical standpoint for hospitals to understand that to keep employees they need to focus their efforts on reducing and preventing hostile interactions between coworkers. Giving leaders aggression prevention training, strictly enforcing organizational policies that forbid hostility between coworkers, and ensuring that people have open channels of communication for voicing concerns are all important for reducing the negative effects that aggression victimization has (Hershcovis \& Barling, 2009). It may also be important to provide nurses with more realistic job previews before they are hired, so they know what they are getting into.

\section{Limitations}

Considering there are no fully supported hypotheses, it is worth mentioning some important limitations of this study. First, this study is based on archival data that were not originally conceived for the purpose of this paper. Because of this, potential mediator variables like emotion regulation and other relevant outcomes could not be accounted for. For example, organizational commitment was not in the data, but could have provided this study with greater richness, because it has been shown to be an important job retention factor. Also, as mentioned at the end of the results summary section, prosocial impact rather than prosocial motivation would have been the preferred variable to assess for the second hypothesis. Future research should integrate organizational commitment and prosocial impact into this model, along with other retention factors.

Second, this study is cross-sectional, and because of this I cannot infer causation. Although I may find that my variables of interest (retention factors) are predicted differently by different sources of aggression, I cannot say that these sources of 
aggression cause certain levels in retention factors. Not having measurement of all variables from multiple time points separated by a specific time interval with an experimental design limited my ability to claim any causality (Zapf, Dormann, \& Frese, 1996; Ployhart \& Vandenberg, 2010). Future research should attempt to use an experimental design that takes advantage of longitudinal data to examine if different sources of aggression truly cause differences in retention variables. Weekly or monthly diaries may be a promising design for this study where the data would allow for linkages between changes in retention factors, and instances of specific aggression victimization by certain source groups (i.e. LIPs, coworkers, or patients). This would allow for better inferences of causality since changes in the dependent variables could be more closely attributed to instances of aggression.

The third limitation is the sample size. With 337 participants, the sample may not be large enough to accurately detect significant differences between sources of aggression, and may have especially been a problem for the interaction hypothesis $(\mathrm{H} 2)$. Power is somewhat low with this sample size, and recruiting more nurses to take the survey might improve the quality of the results. There were multiple hypotheses that were partially supported, but were trending towards being fully supported. A larger sample size might have remedied this issue.

Lastly, the use of self-report measures in the present study may bias the results. Participants may not even report aggression exposure if they perceived it as low intensity or are fearful about reporting it. Participants that have been exposed to past aggression or are over-vigilant in reporting may also have self-selected into this study. However, the 
aforementioned potential biases due to self-report measures may not be too concerning in this data set since all nurses' information was confidential, and the data is mostly representative of the overall nursing population at the healthcare organization (Yang et al., 2014).

\section{Contributions}

There are several contributions that this study may have for theory and practice. First, to the best of this author's knowledge there is little research on how different sources of aggression differentially predict career commitment. Because the nursing shortage is a serious issue (De Gieter et al., 2011), it is important that we examine what the root cause of this shortage is, and pinpoint where interventions may be most cost effective. Specifically, if we can understand what sources of aggression are more detrimental to career commitment (like patient aggression in the case of this study), then we may better understand where we need to intervene to reduce the rate of professional turnover in the long run. However, because the hypothesis 1c was only partially supported, it is unclear from this study that career commitment is primarily affected by patient aggression. Further research needs to examine career commitment in light of multi-foci aggression. This study can strengthen the multi-foci aggression literature by showing that career commitment is an important outcome that is differentially predicted by different sources of aggression.

Second, this is one of few studies to this author's knowledge that has examined prosocial motivation as a possible coping or emotion-regulation mechanism within the transactional stress model framework. Although a great deal of stress research utilizes 
this model, the idea that a tendency or personality trait like prosocial motivation can act as a coping mechanism and has implications for other-orientation theory and for practice. While prosocial motivation did not act as a buffer in this study, it may still be a variable of interest in a differently designed study with a larger sample size. Overall, this research has the potential to contribute to the occupational health psychology literature.

Lastly, this study is examined aggression from licensed independent practioners (LIPs) and patients, which have not been widely studied in the aggression literature. LIPs and patients may be qualitatively different from supervisors and customers respectively, they showed to some extent different effects in this study. This may further inform multifoci research in healthcare, and show that these healthcare roles are not equivalent to other employee roles in other industries. 


\section{Figures}

Figure 1: Conceptual Model-Multi-Foci Aggression and Prosocial Motivation as Moderators

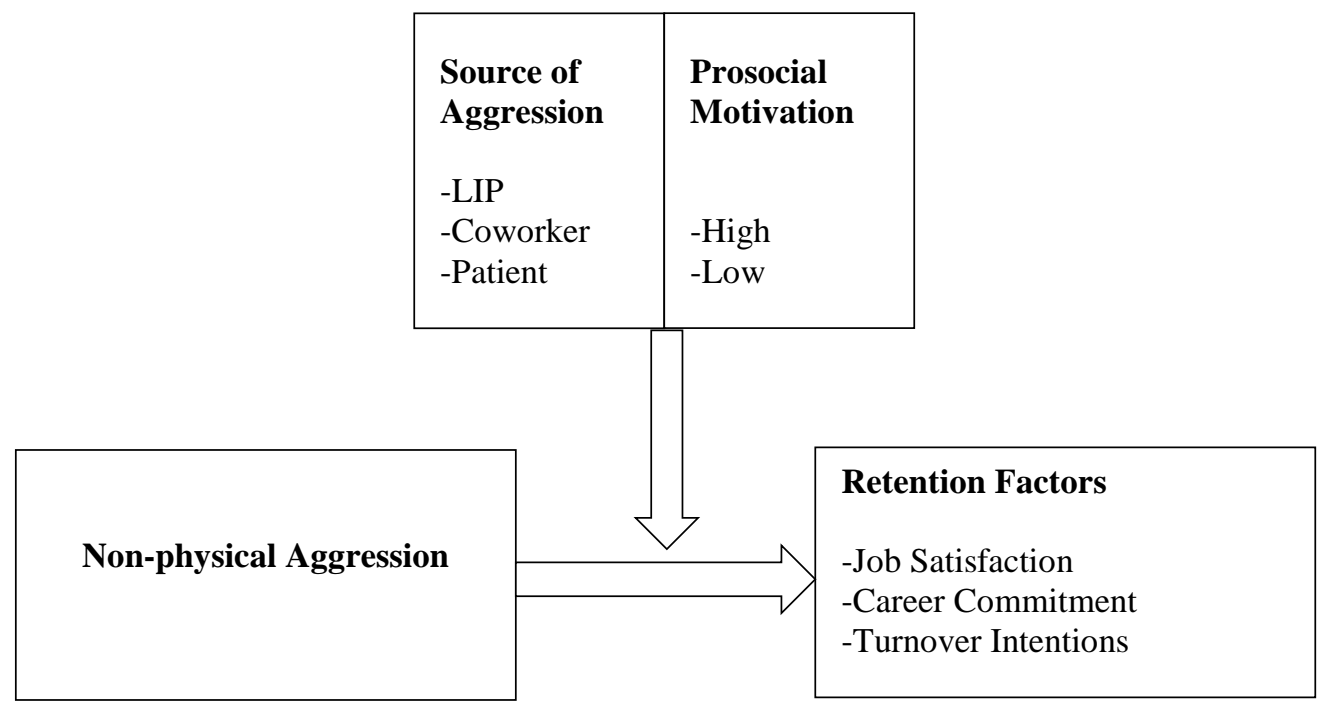


Figure 2: Summary of the Workplace Aggression Nomological Network

\begin{tabular}{|c|c|c|}
\hline & \multicolumn{2}{|c|}{ Workplace Aggression Nomological Network } \\
\hline \multirow{7}{*}{ 䓀 } & Individual-Level Variables & Situational-Level Variables \\
\hline & Demographic Antecedents & Workplace Antecedents \\
\hline & $\begin{array}{c}\text { Gender } \\
\text { History with Aggression } \\
\text { Bachelor's vs. Master's }\end{array}$ & $\begin{array}{c}\text { Night Shift Work } \\
\text { Job Autonomy } \\
\text { Workload }\end{array}$ \\
\hline & Socio-emotional Antecedents & Environmental Antecedents \\
\hline & $\begin{array}{c}\text { Trait NA } \\
\text { Anxiety } \\
\text { Self-control }\end{array}$ & $\begin{array}{c}\text { Crowding } \\
\text { Humidity } \\
\text { Lacking Personal Protective Equipment }\end{array}$ \\
\hline & & Psychosocial Antecedents \\
\hline & & $\begin{array}{c}\text { Poor Leadership } \\
\text { Lacking Social Support } \\
\text { Poor Violence Prevention Climate }\end{array}$ \\
\hline \multirow{4}{*}{ 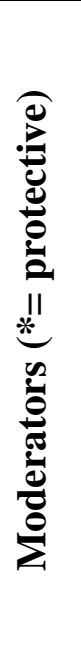 } & Individual-level Moderators & Organizational Moderators \\
\hline & $\begin{array}{c}\text { *Self-control } \\
* \text { Generalized Self-Efficacy }\end{array}$ & $\begin{array}{c}\text { *Percieved Organizational Support } \\
\text { (POS) } \\
\text { *Job Mobility } \\
\text { *Psychosocial Safety Climate }\end{array}$ \\
\hline & & Relational Moderators \\
\hline & & $\begin{array}{c}\text { *Social Support } \\
\text { Power Differential } \\
\text { Task Interdependence } \\
\text { Relational Connectedness }\end{array}$ \\
\hline
\end{tabular}


Figure 2 Continued.

\begin{tabular}{|c|c|}
\hline \multirow{17}{*}{ : } & Well-Being Outcomes \\
\hline & Depression \\
\hline & Anxiety \\
\hline & Post-Traumatic Stress Disorder \\
\hline & Chronic Pain \\
\hline & Muscle Tension \\
\hline & Behavioral Outcomes \\
\hline & Wasting organizational resources \\
\hline & Absenteeism \\
\hline & Being Late \\
\hline & Attitudinal Outcomes \\
\hline & Life Satisfaction \\
\hline & Job Satisfaction \\
\hline & Organizational Commitment \\
\hline & Job Morale \\
\hline & Turnover Intention \\
\hline & Career Commitment \\
\hline
\end{tabular}




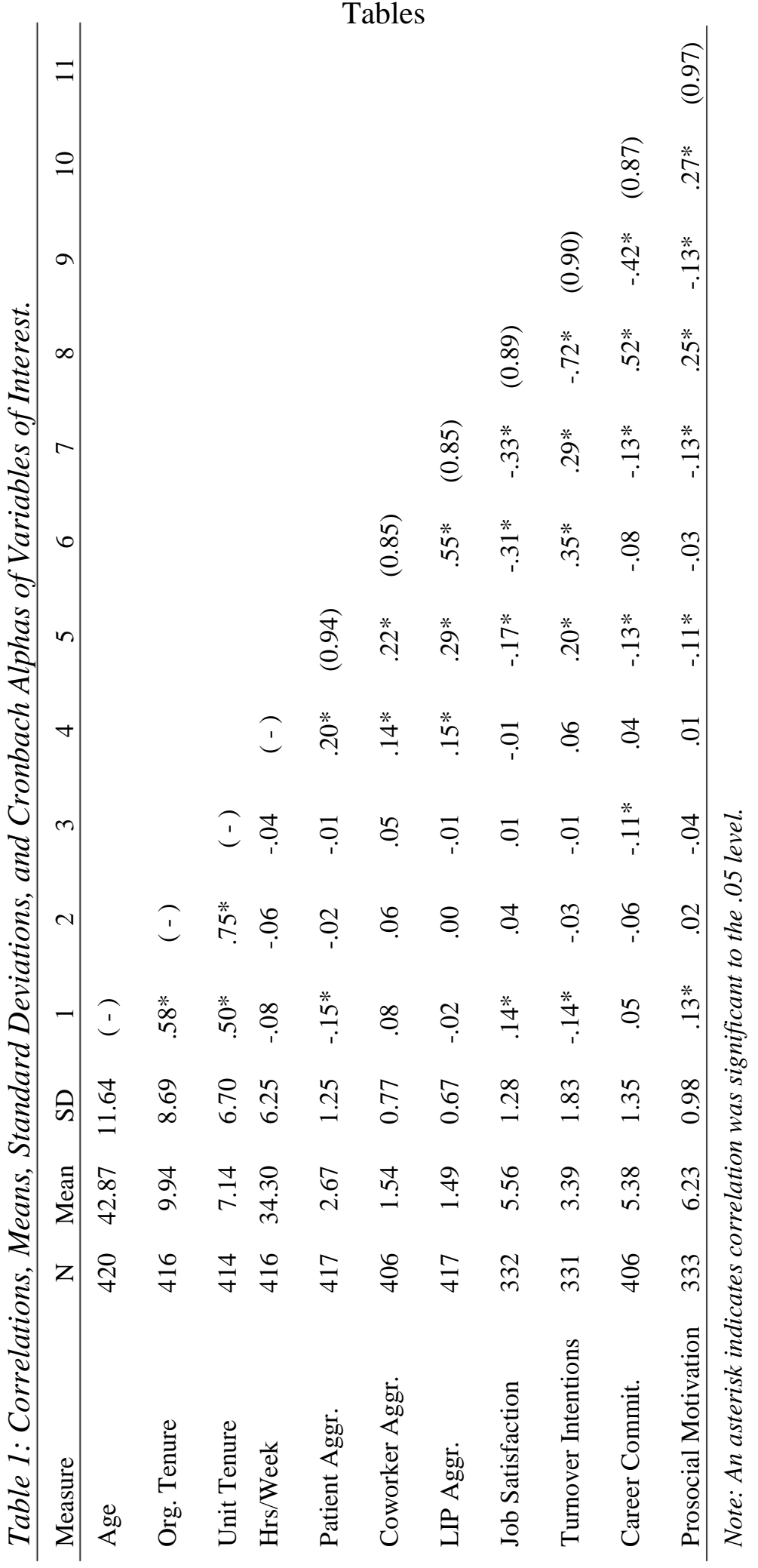


Table 2: Hierarchical Linear Regression for Job Satisfaction.

\begin{tabular}{lcrrrrr}
\multicolumn{1}{c}{ Predictors } & R2 & $\begin{array}{c}\text { R2 } \\
\text { Change }\end{array}$ & F-change & Std. $\beta$ & Std. Error & $\begin{array}{r}\text { P- } \\
\text { value }\end{array}$ \\
\hline Model 1 & 0.02 & 0.02 & 1.609 & & & \\
Age & & & & 0.166 & 0.008 & 0.016 \\
Org. Tenure & & -0.017 & 0.013 & 0.846 \\
Unit Tenure & & -0.053 & 0.016 & 0.537 \\
Hours worked per Week & & & 0.003 & 0.011 & 0.954 \\
& & & & & & \\
Model 2 & & & & & \\
Age & 0.166 & 0.146 & 18.324 & & 0.007 & 0.004 \\
Org. Tenure & & & -0.024 & 0.012 & 0.771 \\
Unit Tenure & & & -0.032 & 0.015 & 0.682 \\
Hours worked per Week & & & 0.078 & 0.010 & 0.145 \\
LIP Aggression & & & -0.204 & 0.124 & 0.002 \\
Coworker Aggression & & & -0.213 & 0.099 & 0.001 \\
Patient Aggression & & & -0.055 & 0.058 & 0.33 \\
\hline
\end{tabular}

Table 3: Hierarchical Linear Regression for Turnover Intentions.

\begin{tabular}{|c|c|c|c|c|c|c|}
\hline Predictors & $\mathbf{R 2}$ & $\begin{array}{c}\mathbf{R 2} \\
\text { Change }\end{array}$ & F-change & $\begin{array}{c}\text { Std. } \\
\beta\end{array}$ & Std. Error & $\begin{array}{r}P- \\
\text { value }\end{array}$ \\
\hline Model 1 & 0.010 & 0.022 & 1.805 & & & \\
\hline Age & & & & -0.165 & 0.011 & 0.017 \\
\hline Org. Tenure & & & & 0.033 & 0.019 & 0.714 \\
\hline Unit Tenure & & & & 0.043 & 0.023 & 0.613 \\
\hline Hours worked per Week & & & & 0.046 & 0.015 & 0.409 \\
\hline Model 2 & 0.157 & 0.153 & 19.350 & & & \\
\hline Age & & & & -0.185 & 0.010 & 0.004 \\
\hline Org. Tenure & & & & 0.038 & 0.017 & 0.647 \\
\hline Unit Tenure & & & & 0.022 & 0.021 & 0.775 \\
\hline Hours worked per Week & & & & -0.034 & 0.015 & 0.519 \\
\hline LIP Aggression & & & & 0.101 & 0.176 & 0.115 \\
\hline Coworker Aggression & & & & 0.296 & 0.140 & 0.000 \\
\hline Patient Aggression & & & & 0.095 & 0.082 & 0.094 \\
\hline
\end{tabular}


Table 4: Hierarchical Linear Regression for Career Commitment.

\begin{tabular}{|c|c|c|c|c|c|c|}
\hline Predictors & $\mathbf{R 2}$ & $\begin{array}{c}\mathbf{R 2} \\
\text { Change }\end{array}$ & $\begin{array}{c}\text { F- } \\
\text { change }\end{array}$ & Std. $\beta$ & Std. Error & $\begin{array}{r}\text { P- } \\
\text { value }\end{array}$ \\
\hline Model 1 & 0.017 & 0.028 & 2.392 & & & \\
\hline Age & & & & 0.138 & 0.008 & 0.039 \\
\hline Org. Tenure & & & & -0.009 & 0.014 & 0.915 \\
\hline Unit Tenure & & & & -0.172 & 0.017 & 0.040 \\
\hline Hours worked per Week & & & & 0.056 & 0.011 & 0.308 \\
\hline Model 2 & 0.036 & 0.028 & 3.230 & & & \\
\hline Age & & & & 0.128 & 0.008 & 0.058 \\
\hline Org. Tenure & & & & -0.005 & 0.014 & 0.957 \\
\hline Unit Tenure & & & & -0.165 & 0.017 & 0.047 \\
\hline Hours worked per Week & & & & 0.098 & 0.012 & 0.082 \\
\hline LIP Aggression & & & & -0.094 & 0.138 & 0.163 \\
\hline Coworker Aggression & & & & -0.020 & 0.111 & 0.757 \\
\hline Patient Aggression & & & & -0.104 & 0.064 & 0.081 \\
\hline
\end{tabular}


Table 5: Hierarchical Linear Regression for Career Commitment With Patient Aggression x Prosocial Motivation

\begin{tabular}{|c|c|c|c|c|c|c|}
\hline Predictors & $\mathbf{R 2}$ & $\begin{array}{c}\mathbf{R 2} \\
\text { Change } \\
\end{array}$ & F-change & $\begin{array}{c}\text { Std. } \\
\beta\end{array}$ & Std. Error & $\begin{array}{c}\text { P- } \\
\text { value }\end{array}$ \\
\hline Model 1 & 0.014 & 0.027 & 2.171 & & & \\
\hline Age & & & & 0.143 & 0.008 & 0.036 \\
\hline Org. Tenure & & & & -0.026 & 0.014 & 0.772 \\
\hline Unit Tenure & & & & -0.151 & 0.017 & 0.075 \\
\hline Hours worked per Week & & & & 0.057 & 0.011 & 0.310 \\
\hline Model 2 & 0.086 & 0.077 & 13.475 & & & \\
\hline Age & & & & 0.074 & 0.008 & 0.268 \\
\hline Org. Tenure & & & & -0.022 & 0.013 & 0.796 \\
\hline Unit Tenure & & & & -0.110 & 0.016 & 0.179 \\
\hline Hours worked per Week & & & & 0.080 & 0.011 & 0.147 \\
\hline Prosocial Motivation & & & & 0.242 & 0.075 & 0.000 \\
\hline Patient Aggression & & & & -0.126 & 0.060 & 0.024 \\
\hline Model 3 & 0.084 & 0.001 & 0.187 & & & \\
\hline Age & & & & 0.073 & 0.008 & 0.274 \\
\hline Org. Tenure & & & & -0.023 & 0.013 & 0.787 \\
\hline Unit Tenure & & & & -0.112 & 0.016 & 0.174 \\
\hline Hours Worked Per Week & & & & 0.079 & 0.011 & 0.154 \\
\hline Prosocial Motivation & & & & 0.239 & 0.076 & 0.000 \\
\hline Patient Aggression & & & & -0.125 & 0.06 & 0.025 \\
\hline Pat Aggr. X Prosocial Motiv & & & & 0.024 & 0.056 & 0.666 \\
\hline
\end{tabular}




\section{References}

Aguinis H., Beaty, J., Boik, R. J., \& Pierce, C. A. (2005). Effect size and power in assessing moderating effects of categorical variables using multiple regression: A 30-year review. Journal of Applied Psychology, 90, 94-107.

Andersson, L.M. (1999). Tit for tat? The spiraling effect of incivility in the workplace. The Academy of Management Review, 24, 452-471.

Andrews, D.R., \& Dziegielewski, S.F. (2005). The nurse manager: Job satisfaction, the nursing shortage and retention. Journal of Nursing Management, 13, 286-295.

Aquino, K., \& Bradfield, M. (2000). Perceived victimization in the workplace: The role of situational factors and victim characteristics. Organization Science, 11, 525537.

Aquino, K., \& Douglas, S. (2003). Identity threat and antisocial behavior in organizations: The moderating effects of individual differences, aggressive modeling, and hierarchical status. Organizational Behavior and Human Decision Processes, 90, 195-208.

Aquino, K., \& Thau, S. (2009). Workplace victimization: Aggression from the target's perspective. Annual Review of Psychology, 60, 717-741.

Aryee, S. \& Tan, K. (1992). Antecedents and outcomes of career commitment. Journal of Vocational behavior, 40, 288-305.

Astrom, S., Bucht, G., Eisemann M., Norberg, A., \& Saveman, B.-I. (2002). Incidence of violence towards staff caring for the elderly. Scandinavian Journal of Caring Sciences, 16, 66-72. 
Aytaç, S., \& Dursun, S. (2012). The effect on employees of violence climate in the workplace. Work: A Journal of Prevention, Assessment and Rehabilitation, 41, 3026-3031.

Baron, R.A. \& Neuman, J.H. (1996). Workplace violence and workplace aggression: Evidence on their relative frequency and potential causes. Aggressive Behavior, 22(3), 161-173.

Barclay, L. J., \& Aquino, K. (2011). Workplace aggression and violence. In S. Zedeck (Ed.), APA Handbook of Industrial and Organizational Psychology (Vol. 3, pp. 615-640). Washington, DC: American Psychological Association.

Barling, J., Dupre, K. E., \& Kelloway, K. E. (2009). Predicting workplace aggression and violence. The Annual Review of Psychology, 60, 671-692.

Barling, J., Kelloway, E. K., \& Frone, M. R. (2004). Handbook of Work Stress. Thousand Oaks, CA: Sage.

Batson, C.D. (1987). Prosocial motivation: Is it ever truly altruistic? In L. Berkowitz (Ed.), Advanes in Experimental and Social Psychology, (Vol. 20, pp. 65-122). New York, NY: Academic Press.

Bedeian, A.G., Kemery, E.R., \& Pizzolatto, A.B. (1991). Career commitment and expected utility of present job as predictors of turnover intentions and turnover behaviors. Journal of Vocational Behavior, 39, 331-343.

Bennet, R.J. (2000). Development of a measure of workplace deviance. Journal of Applied Psychology, 85(3), 349-360. 
Bies, R. J., \& Tripp, T. M. (2005). The study of revenge in the workplace: conceptual, ideological, and empirical issues. In S. Fox \& P. E. Spector (Eds.), Counterproductive Work Behavior: Investigations of actors and targets (pp. 6581). Washington, DC: American Psychological Association.

Blau, G.J. (1985). The measurement and prediction of career commitment. Journal of Occupational Psychology, 58, 277-288.

Blau, G. (1989). Testing the generalizability of a career commitment measure and its impact on employee turnover. Journal of Vocational Behavior, 35, 88-103.

Blau, G., \& Andersson, L. (2005). Testing a measure of instigated workplace incivility. Journal of Occupational and Organizational Psychology, 78(4), 595-614.

Blegen, M. (1993). Nurses' job satisfaction: a meta-analysis of related variables. Nursing Research, 42, 36-41.

Bliese, P.D. (2000). Within-group agreement, non-independence, and reliability: Implications for data aggregation and analysis. In K.J. Klein \& S.W.J. Kozlowski (Eds.), Multilevel Theory, Research, and Methods in Organizations: Foundations, Extensions, and New Directions (pp. 349-381). San Francisco, CA, US: JosseyBass.

Bobocel, R.D. (2013). Coping with unfair events constructively or destructively: The effects of overall justice and self-other orientations. Journal of Applied Psychology, 98, 720-731. 
Boswell, W., \& Olson-Buchanan, J. (2004). Experiencing mistreatment at work: the role of grievance filing, nature of mistreatment, and employee withdrawal. Academy of Management Journal, 47, 129-139.

Bowling, N.A., \& Beehr, T.A. (2006). Workplace harassment from the victim's perspective: A theoretical model and meta-analysis. Journal of Applied Psychology, 91, 998-1012.

Burks, D.J., Youll, L.K., \& Durtschi, J.P. (2012). The empathy-altruism association and its relevance to health care professions. Social Behavior and Personality, 40, 395400.

Chang, C.-H., Chen, S.-Y., \& Lan, Y.T. (2011) Raising nurses' job satisfaction through patient-oriented perception and organizational citizenship behaviors. Nursing Research, 60, 40-46.

Chang, C.-H., \& Lyons, B.J. (2012). Not all aggressions are created equal: A multifoci approach to workplace aggression. Journal of Occupational Health Psychology, $17,79-92$.

Chang, E. (1999). Career commitment as a complex moderator of organizational commitment and turnover intention. Human Relations, 52, 1257-1278.

Chen, W. C., Hwu, H. G., Kung, S. M., Chiu, H. J., \& Wang, J. D. (2008). Prevalence and determinants of workplace violence of health care workers in a psychiatric hospital in Taiwan. Journal of Occupational Health Psychology, 50(3), 288-293. 
Chen, P. Y., \& Spector, P. E. (1992). Relationships of work stressors with aggression, withdrawal, theft and substance use: an exploratory study. Journal of Occupational and Organizational Psychology, 65, 177-184.

Chiaburu, D.S. \& Harrison, D.A. (2008). Do peers make the place? Conceptual synthesis and meta-analysis of coworker effects on perceptions, attitudes, OCBs, and performance. Journal of Applied Psychology, 93, 1082-1103.

Chi, S.-C.S., \& Liang, S.-G. (2012). When do subordinates' emotion-regulation strategies matter? Abusive supervision, subordinates' emotional exhaustion, and work withdrawal. The Leadership Quarterly, 24, 125-137.

Colarelli, S.M. \& Bishop, R.C. (1990). Career commitment: Functions, correlates, and management. Group \& Organization Studies, 15, 158-176.

Cruce, T. M., \& Hillman, N. W. (2012). Preparing for the silver tsunami: The demand for higher education among older adults. Research in Higher Education, 53(6), 593613.

De Dreu, C.K.W. (2006). Rational self-interest and other-orientation in organizational behavior: A critical appraisal and extension of Meglino and Korsgaard (2004). Journal of Applied Psychology, 91, 1245-1252.

De Dreu, C.K.W., \& Nauta, A. (2009). Self-interest and other-orientation in organizational behavior: Implications for job performance, prosocial behavior, and personal initiative. Journal of Applied Psychology, 94, 913-926. 
De Gieter, S., Hofmans, J., \& Pepermans, R. (2011). Revisiting the impact of job satisfaction and organizational commitment on nurse turnover intention: An individual differences analysis. International Journal of Nursing Studies, 48, $1562-1569$.

Deery, S., Walsh, J., \& Guest, D. (2011). Workplace aggression: The effects of harassment on job burnout and turnover intentions. Work Employment Society, 25, $742-759$.

Demir, D., \& Rodwell, J. (2012). Psychosocial antecedents and consequences of workplace aggression for hospital nurses. Journal of nursing scholarship : an official publication of Sigma Theta Tau International Honor Society of Nursing / Sigma Theta Tau, 44, 376-384.

Djurkovic, N., McCormack, D., \& Casimir, G. (2008). Workplace bullying and intention to leave: The moderating effect of perceived organizational support. Human Resource Management Journal, 18, 405-422.

Dohm, A. (2000). Guaging the labor force effects of retiring baby-boomers. Monthly Lab. Rev., 123, 17-25.

Douglas, S. C., \& Martinko, M. J. (2001). Exploring the role of individual differences in the prediction of workplace aggression. Journal of Applied Psychology, 86, 547559. 
Dupré, K.E., \& Barling, J. (2003). Workplace aggression. In A. Sagie, M. Koslowsky, \& S. Stashervsky (Eds.), Misbehaviour and dysfunctional attitudes in organisations. New York: Palgrave Macmillan

Durhart, D.T. (2001). Violence in the workplace, 1993-99. Bureau of Justice Statistics: Special Report,1-12.

Einarsen, S., \& Raknes, B.I. (1997). Harassment in the workplace and the victimization of men. Violence \& Victims, 12(3), 247-263.

Estryn-Behar, M., van der Heijden, B., Fry, C., \& Hasselhorn, H.-M. (2010). Longitudinal analysis of personal and work-related factors associated with turnover among nurses. Nursing Research, 59, 166-177.

Fagermoen, M.S. (1997). Professional identity: Values embedded in meaningful nursing practice. Journal of Advanced Nursing, 25, 434-441.

Farrell, G. A., Shafiei, T., \& Chan, S.-P. (2013). Patient and visitor assault on nurses and midwives: An exploratory study of employer "protective" factors. International journal of mental health nursing.

Faul, F., Erdfelder, E., Lang, A.-G., \& Buchner, A. (2007). G*Power 3: A flexible statistical power analysis program for the social, behavioral, and biomedical sciences. Behavior Research Methods, 39, 175-191.

George, J. M., \& Jones, G. R. (1996). The experience of work and turnover intentions: Interactive effects of value attainment, job satisfaction, and positive mood. Journal of Applied Psychology, 81, 318-325. 
Gerberich, S.G., Church, T.R., McGovern, P.M., Hansen, H.E., Nachreiner, N.M., Geisser, A.D., Ryan, A.D., Mongin, S.J. (2004). An epidemiological study of the magnitude and consequences of work related violence: The Minnesota nurses' study. Occupational Environmental Medicine, 61, 495-503.

Grandey, A.A. (2004). The customer is not always right: Customer aggression and emotional regulation of service employees. Journal of Organizational Behavior, 25(3), 397-418.

Grant, A.M. (2007). Relational job design and the motivation to make a prosocial difference. Academy of Management Review, 32, 393-417.

Grant, A.M. (2008). Does intrinsic motivation fuel the prosocial fire? Motivational synergy in predicting persistence, performance, and productivity. Journal of Applied Psychology, 93, 48-58.

Grant, A.M., \& Rothbard, N.P. (2013). When in doubt, seize the day? Security values, prosocial values, and proactivity under ambiguity. Journal of Applied Psychology, 98, 810-819.

Grant, A.M., \& Sonnentag, S. (2010). Doing good buffers against feeling bad: Prosocial impact compensates for negative task and self-evaluations. Organizational Behavior and Human Decision Processes, 111, 13-22.

Hahn, S., Zeller, A., Needham, I., Kok, G., Dassen, T., \& Halfens, R. J. G. (2008). Patient and visitor violence in general hospitals: A systematic review of the literature. Aggression and Violent Behavior, 13, 431-441. 
Hansen, A. M., Hogh, A., Persson, R., Karlson, B., Garde, A. H., \& Orbaek, P. (2006). Bullying at work, health outcomes, and physiological stress reponse. Journal of Psychosomatic Research, 60, 63-72.

Hayes, L.J., O’Brien-Pallas, L., Duffield, C., Shamian, J., Buchan, J., Hughes, F., Laschinger, H., North, N., \& Stone, P.W. (2006). Nurse turnover: A literature review. International Journal of Nursing Studies, 43, 237-263.

Hershcovis, M. S., \& Barling, J. (2006). Preventing workplace violence. In E. K. Kelloway, J. Barling, \& J. Hurrell (Eds.), Handbook of Workplace Violence (pp. 607-632). Thousand Oaks, CA: Sage.

Hershcovis, S.M., \& Barling, J. (2007). Towards a relational model of workplace aggression. In J. Langan-Fox, C. L. Cooper, \& R. J. Klimoski (Eds.), Research companion to the dysfunctional workplace (pp. 268-284). Cheltenham, UK: Edward Elgar Publishing Ltd.

Hershcovis, S.M., \& Barling, J. (2010). Towards a multi-foci approach to workplace aggression: A meta-analytic review of outcomes from different perpetrators. Journal of Organizational Behavior, 31, 24-44.

Hershcovis, S.M., Turner, N., Barling, J., Arnold, K.A., Dupre, K.E., Inness, M., LeBlanc, M.M., \& Sivanathan, N. (2007). Predicting workplace aggression: A meta-analysis. Journal of Applied Psychology, 92, 228-238. 
Hershcovis, S.M., \& Reich, T.C. (2013). Integrating workplace aggression research: Relational, contextual, and method considerations. Journal of Organizational Behavior.

Hickey, R. (2013). Prosocial motivation, stress and burnout among direct support workers. Journal of Applied Research in Intellectual Disabilities.

Johnson J.V., \& Hall, E.M. (1988). Job strain, work place social support, and cardiovascular disease: A cross-sectional study of a random sample of the Swedish working population. American Journal of Public Health, 78, 1336-1342.

Johnson, J. W. (2000). A heuristic method for estimating the relative weight of predictor variables in multiple regression. Multivariate Behavioral Research, 35, 1-19.

Karasek, R.A. (1979). Job demands, job decision latitude, and mental strain: Implications for job redesign. Administrative Science Quarterly, 24, 285-308.

Knickman, J. R., \& Snell, E. K. (2002). The 2030 problem: caring for aging baby boomers. Health services research, 37, 849-884.

Korsgaard, M.A., Meglino, B.M., \& Lester, S.W. (1996). The effect of other-oriented values on decision making: A test of propositions of a theory of concern for others in organizations. Organizational Behavior and Human Decision Processes, 68, 234-245.

Korsgaard, M.A., Meglino, B.M., Thomas, D., \& Au, K. (2001). How deliberative are employee responses to violations of expectations? Paper presented at the annual 
meeting of the Socity for Industrial and Organizational Psychology, San Diego, CA.

Lazarus R.S., \& Folkman, S. (1984). Stress, Appraisal, and Coping. New York, NY: Springer Publishing Company, Inc.

LeBlanc, M.M., \& Kelloway, E.K. (2002). Predictors and outcomes of workplace violence and aggression. Journal of Applied Psychology, 87, 444-453.

Leiter M.P., \& Maslach, C. (2009). Nurse turnover: The mediating role of burnout. Journal of Nursing Management, 17, 331-339.

Lester, S.W., Meglino, B.M., \& Korsgaard, M.A. (2002). Social and non-social exchange relationships in team directed organizational citizenship behaviors. Paper presented at the annual meeting of the Academy of Management, Denver, CO.

Light, P. C. (1988). Baby boomers.

Lu, K.-Y., Lin, P.-L., Wu, C.-M., Hsieh, Y.-L., \& Chang, Y.-Y. (2002). The relationships among turnover intentions, professional commitment, and job satisfaction of hospital nurses. Journal of Professional Nursing, 18, 214-219.

Lu, H., While, A.E., \& Barriball, K.L. (2005). Job satisfaction among nurses: A literature review. International Journal of Nursing Studies, 42, 211-227.

Meglino, B.M., \& Korsgaard, A. (2004). Considering rational self-interest as a disposition: Organizational implications of other-orientations. Journal of Applied Psychology, 89, 946-959.

Meglino, B.M., \& Korsgaard, M.A. (2007). The role of other orientation in reactions to job characteristics. Journal of Management, 33, 57-83. 
Mobley, W.H. (1977). Intermediate linkages in the relationship between job satisfaction and employee turnover. Journal of Applied Psychology, 62, 237-240.

Mobley, W. H., Horner, S. O., Hollingsworth, A. T. (1978). An evaluation of precursors of hospital employee turnover. Journal of Applied Psychology, 63, 408-414.

Mor Barak, M. E., Nissly, J. A., \& Levin, A. (2001). Antecedents to retention and turnover among child welfare, social work, and other human service employees: what can we learn from past research? a review and meta-analysis. Social Service Review, 75, 625-661.

Needham, I., Abderhalden, C., Halfens, R.J.G., Fischer, J.E., \& Dassen, T. (2005). Nonsomatic effects of patient aggression on nurses: A systematic review. Journal of Advanced Nursing, 49, 283-296.

Neuman, J. H., \& Baron, R. A. (1998). Workplace violence and workplace aggression: Evidence concerning specific forms, potential causes, and preferred targets. Journal of Management, 24(3), 391-419.

Neuman, J. H., \& Baron, R. A. (2005). Aggression in the workplace: A socialpsychological perspective. In S. Fox \& P. E. Spector (Eds.), Counterproductive work behavior: Investigations of actors and targets (pp. 13-40). Washington, DC: American Psychological Association.

O’Connell, B., Young, J., Brooks, J., Hutchings, J., Lofthouse, J. (2000). Nurses' perceptions of the nature and frequency of aggression in general ward settings and high dependency areas. Journal of Clinical Nursing,9(4), 602-610. 
O’Connor, B. P. (2006). Programs for problems created by continuous variable distributions in moderated multiple regression. Organizational Research Methods, 9(4), 554-567.

Ogunfowora, B. (2013). When the abuse is unevenly distributed: The effects of abusive supervision variability on work attitudes and behavior. Journal of Organizational Behavior, 34, 1105-1123.

Pai, H.-C., \& Lee, S. (2011). Risk factors for workplace violence in clinical registered nurses in Taiwan. Journal of clinical nursing, 20, 1405-1412.

Parry, J. (2008). Intention to leave the profession: Antecedents and role in nurse turnover. Journal of Advanced Nursing, 64, 157-167.

Pimlott-Kubiak, S., \& Cortina, L.M. (2003). Gender, victimization, and outcomes: reconceptualizing risk. Journal of Consulting and Clinical Psychology, 71, 528539.

Ployhart, R. E., \& Vandenberg, R. J. (2010). Longitudinal research: The theory, design, and analysis of change. Journal of Management, 36, 94-120.

Raudenbush, S. W. \& Bryk, A. S. (2002). Hierarchical Linear Models: Applications and Data Analysis Methods. Thousand Oaks, CA: Sage.

Restubog, S., Zagencyzk, T., Bordia, P., Bordia, S., \& Chapman, G. (2012). If you wrong us, shall we not revenge? Moderating roles of self-control and perceived aggressive work culture in predicting responses to psychological contract breach. Journal of Management, 1-23. 
Rospenda, K. (2002). Workplace harassment, services utilization, and drinking outcomes. Journal of Occupational Health Psychology, 7(2), 141-155.

Schat, A. C. H., \& Frone, M. R. (2011). Exposure to psychological aggression at work and job performance: The mediating role of job attitudes and personal health. Work \& Stress, 25, 23-40.

Schat, A. C. H., Frone, M. R., \& Kelloway, E. K. (2006). Prevalence of workplace aggression in the U.S. workforce: Findings from a national study. In E. K. Kelloway, J. Barling, \& J. J. Hurrell (Eds.), Handbook of Workplace Violence (pp. 47-89). Thousand Oaks, CA: Sage.

Schat, A. C. H., \& Kelloway, E. K. (2003). Reducing the adverse consequences of workplace aggression and violence: the buffering effects of organizational support. Journal of Occupational Health Psychology, 8, 110-122.

Schat, A.C. \& Kelloway, E.K. (2005). Workplace Aggression. In J. Barling, E.K. Kelloway, \& M.R. Frone (Eds.), Handbook of Work Stress (pp. 189-218). Thousand Oaks, CA: Sage Publications, Inc.

Shoghi, M., Sanjari, M., Shirazi, F., Heidari, S., Salemi, S., \& Mirzabeigi, G. (2008). Workplace violence and abuse against nurses in hospitals in Iran. Asian Nursing Research, 2(3), 184-193.

Skarlicki, D. P., \& Folger, R. (1997). Retaliation in the workplace: the roles of distributive, procedural, and interactional justice. Journal of Applied Psychology, $82,434-443$. 
Spector, P.E. (1997). Job satisfaction: Application, assessment, causes, and consequences. Thousand Oaks, CA: Sage Publications, Inc.

Spector, P. E., Coulter, M. L., Stockwell, H. G., \& Maltz, M. W. (2007). Perceived violence climate: a new construct and its relationship to workplace physical violence and verbal aggression, and their potential consequences. Work \& Stress, 21, 117-130.

Spector, P. E., \& Jex, S. M. (1998). Development of four self-report measures of job stressors and strain: Interpersonal conflict at work scale, organizational constraints scale, quantitative workload inventory, and physical symptoms inventory. Journal of Occupational Health Psychology, 3, 356-367.

Spector, P. E., \& O’Connell, B. J. (1994). The contribution of personality traits, negative affectivity, locus of control and Type A to the subsequent reports of job stressors and job strains. Journal of Occupational and Organizational Psychology, 67, 111.

Tabachnick, B., \& Fidell, L.S. (2013). Using Multivariate Statistics (6 ${ }^{\text {th }}$ ed.). Boston, MA: Allyn and Bacon.

Tepper, B.J. (2000). Consequences of abusive supervision. Academy of Management Journal, 43(2), 178-190.

Tepper, B.J. (2007). Abusive supervision in work organizations: Review, synthesis, and research agenda. Journal of Management, 33(3), 261-289. 
Tepper, B.J., \& Henle, C.A. (2011). A case for recognizing distinctions among constructs that capture interpersonal mistreatment in work organizations. Journal of Organizational Behavior, 32, 487-498.

Tett, R.P. \& Meyer, J.P. (1993). Job satisfaction, organizational commitment, turnover intention, and turnover: Path analyses based on meta-analytic findings. Personnel Psychology, 46, 259-293.

Van der Doef, M., \& Maes, S. (1999). The job demand-control(-support) model and psychological well-being: A review of 20 years of empirical research. Work \& Stress, 13(2), 87-114.

Winstanley, S., \& Whittington, R. (2004). Aggression towards health care staff in a UK general hospital: Variation among professions and departments. Journal of Clinical Nursing, 13(1), 3-10.

Yang, L. Q., \& Caughlin, D. E. (2012) Aggression preventative supervisor behavior: Scale development and validation. In D. E. Caughlin, L. Q. Yang, \& C. H. Chang (Chairs), Employee and organizational consequences of aggression prevention climate. Symposium conducted at the meeting of Academy of Management, Boston, MA.

Yang, L.-Q., Caughlin, D.E., Gazica, M.W., Truxillo, D. M., \& Spector, P.E. (In Press). Workplace mistreatment climate: A review of contextual influence from the target's perspective. Journal of Occupational Health Psychology. 
Yang, L. Q., Che, H., \& Spector, P. E. (2008). Job stress and well-being: An examination from the view of person-environment fit. Journal of Occupational and Organizational Psychology, 81, 567-587.

Yang, L. Q., Caughlin, D. E., Novak, K. O., Garcia, A., Do, P., \& Hoang, H. (2014, May). Aggression preventive supervisor behaviors: Good for climate and employee outcomes? Poster presented at the annual meeting of the Society for Industrial-Organizational Psychology, Honolulu, Hawaii.

Yang, L. Q., Spector, P. E., Chang, C. -H., Gallant-Roman, M., \& Powell, J. (2012). Psychosocial precursors and physical consequences of workplace violence towards nurses: A longitudinal examination with naturally occurring groups in hospital settings. International Journal of Nursing Studies, 49(9), 1091-1102.

Zapf, D., Dormann, C., \& Frese, M. (1996). Longitudinal studies in organizational stress research: A review of the literature with reference to methodological issues. Journal of Occupational Health Psychology, 1, 145-169.

Zapf, D., Escartin, J., Einarsen, S., Hoel, H., \& Vartia, M. (2011). Empirical findings on prevalence and risk groups of bullying in the workplace. In S. Einarsen, H. Hoel, D. Zapf, \& C. Cooper (Eds.), Bullying and Harassment in the Workplace: Developments in Theory Research, and Practice (pp. 75-97). Boca Raton, FL: CRC Press.

Zapf, D., \& Gross, C. (2001). Conflict escalation and coping with workplace bullying: A replication and extension. European Journal of Work and Organizational Psychology, 10(4), 497-522. 
Zapf, D., Knorz, C., \& Kulla, M. (1996). On the relationship between mobbing factors, and job content, social work environment, and health outcomes. European Journal of Work and Organizational Psychology, 5(2), 215-237.

Zhang, J., Wu, Q., Miao, D., Yan, X., \& Peng, J. (2013). The impact of core selfevaluations on job satisfaction: The mediator role of career commitment. Social Indicators Research, 116(3), 809-822. 


\section{Appendix}

Survey Items

\section{Acute Care Facility}

1. Which of the following acute care facilities do you primarily work at?

$$
\begin{aligned}
& 1=\text { Providence Hood River Hospital } \\
& 2=\text { Providence Medford Medical Center } \\
& 3=\text { Providence Milwaukie Hospital } \\
& 4=\text { Providence Newberg Medical Center } \\
& 5=\text { Providence Portland Medical Center } \\
& 6=\text { Providence Seaside Hospital } \\
& 7=\text { Providence St } . \text { Vincent Medical Center } \\
& 8=\text { Providence Willamette Falls Medical Center }
\end{aligned}
$$

\section{Nursing Units}

1. If Providence St Vincent, which of the following units do you primarily work in?

1. Anti-Partum

2. Cardiac Telemetry (6W)

3. Cardiology (6E)

4. CICU

5. Dialysis

6. Emergency

7. NCCU

8. IRU

9. IV Therapy

10. Labor, Delivery, and Post-Partum (3W, 4W)

11. Medical East (7E)

12. Medical West (7W)

13. Mental Health - Adult (5E)

14. Neurosurgery (9E)

15. NICU
16. Float Pool - Critical Care

17. Float Pool - Med/Surg

18. Oncology $(5 \mathrm{~W})$

19. Orthopedics (9W)

20. PACU

21. Pediatric - Inpatient (4E)

22. Pediatric - Surgery (Ped OR)

23. PICU

24. Specialty Surgery (8W)

25. Surgical Services - Main OR

26. Surgical Services - Short Stay and PACU

27. Surgical Services - CVOR

28. Surgical Services - Cardiac

29. Surgical Services - Outpatient Eye

30. Surgical Services - MPU (8E)

31. Other (please specify): 
2. If Providence Portland, which of the following units do you primarily work in?

1. Cardiology $(2 \mathrm{G})$

2. $\mathrm{CICU}$

3. Diabetes/Renal (5G)

4. Dialysis

5. Emergency

6. ICU (2F)

7. $\operatorname{ICVR}(2 \mathrm{~K})$

8. IV Therapy

9. Maternity Services (3R-K)

10. Medical Oncology (7N)

11. Surgical Oncology (7S)

12. Medical (5R)

13. Med-Surg Tele
14. Mental Health - Adolescent Child (6L-E)

15. Mental Health - Adult (5L-E)

16. Neurosurgery (8S)

17. Nursing Float Pool

18. Neuro/Uro/Gyn/ENT/Peds (4R)

19. Orthopedics $(8 \mathrm{~N})$

20. Operating Room

21. PACU

22. Rehab (4K)

23. Respiratory Cardiology (2R)

24. Short Stay Surgical (3A)

25. Surgical Oncology (7S)

26. Surgical Unit (3G)

27. Other (please specify):

3. If Providence Medford, which of the following units do you primarily work in?

1. Emergency

2. Float Pool

3. ICU

4. IV Therapy

5. Maternity

6. Medical Telemetry (2W)

7. Medical Unit West
8. Medical Surgical (2E)

9. Neurosurgery (3E)

10. PACU

11. Rehab (3W)

12. Short Stay

13. Other (please specify):

4. If Providence Willamette Falls, which of the following units do you primarily work in?

1. Emergency

2. Medical / Surgical

3. $\mathrm{CCU}$
4. Maternity

5. Surgical Services

6. Other (please specify):

5. If Providence Milwaukie, which of the following units do you primarily work in?

1. Emergency

2. ICU

3. Maternity
4. Medical/Surgical

5. Surgical Services (SS, PACU, OR)

6. Other (please specify) 
6. If Providence Newberg, which of the following units do you primarily work in?
1. Emergency
4. Medical/Surgical
2. ICU
5. Surgical Services (SS, PACU, OR)
3. Maternity
6. Other (please specify):

7. If Providence Seaside, which of the following units do you primarily work in?
1. Emergency
5. Medical / Surgical
2. Extended Care
6. Surgical Services
3. ICU
7. Other (please specify):

4. Maternity

8. If Providence Hood River, which of the following units do you primarily work in?
1. Emergency
5. PACU
2. ICU
6. Short Stay
3. Maternity
7. Surgical Services
4. Medical
8. Other (please specify):

\section{Organizational Tenure}

1. How long have you been working at Providence?

Years

Months

\section{Hours}

1. In a typical employer defined workweek, you actually work hours per week.

\section{Psychological aggression from different sources}

How often have you been subjected to the following behaviors over the past 6 months by [the perpetrator group] (i.e. patients/patients' families, coworkers, or licensed independent practitioners)?

1. Been yelled or shouted at.

1. Never 
2. Once or twice

3. A few times

4. Monthly

5. Weekly

6. Daily

7. Not Applicable

2. Been sworn at.

1. Never

2. Once or twice

3. A few times

4. Monthly

5. Weekly

6. Daily

7. Not Applicable

3. Been glared at.

1. Never

2. Once or twice

3. A few times

4. Monthly

5. Weekly

6. Daily

7. Not Applicable

4. Been threatened verbally or in a written message or note (including e-mail).

1. Never

2. Once or twice

3. A few times

4. Monthly

5. Weekly

6. Daily

7. Not Applicable

5. Been insulted.

1. Never

2. Once or twice

3. A few times

4. Monthly 
5. Weekly

6. Daily

7. Not Applicable

\section{Prosocial Motivation}

Why are you motivated to do your work?

1. Because I care about benefiting others through my work.

1. Strongly Disagree

2. Disagree

3. Moderately Disagree

4. Neither Disagree nor Agree

5. Moderately Agree

6. Agree

7. Strongly Agree

2. Because I want to help others through my work.

1. Strongly Disagree

2. Disagree

3. Moderately Disagree

4. Neither Disagree nor Agree

5. Moderately Agree

6. Agree

7. Strongly Agree

3. Because I want to have a positive impact on others.

1. Strongly Disagree

2. Disagree

3. Moderately Disagree

4. Neither Disagree nor Agree

5. Moderately Agree

6. Agree

7. Strongly Agree

4. Because it is important to me to do good for others through my work.

1. Strongly Disagree

2. Disagree

3. Moderately Disagree

4. Neither Disagree nor Agree

5. Moderately Agree 
6. Agree

7. Strongly Agree

\section{Job Satisfaction}

1. In general, I don't like my job.

1. Strongly Disagree

2. Disagree

3. Moderately Disagree

4. Neither Disagree nor Agree

5. Moderately Agree

6. Agree

7. Strongly Agree

2. All in all, I am satisfied with my job.

1. Strongly Disagree

2. Disagree

3. Moderately Disagree

4. Neither Disagree nor Agree

5. Moderately Agree

6. Agree

7. Strongly Agree

3. In general, I like working here.

1. Strongly Disagree

2. Disagree

3. Moderately Disagree

4. Neither Disagree nor Agree

5. Moderately Agree

6. Agree

7. Strongly Agree

\section{Turnover Intention}

1. I often think of leaving this organization.

1. Strongly Disagree

2. Disagree 
3. Moderately Disagree

4. Neither Disagree nor Agree

5. Moderately Agree

6. Agree

7. Strongly Agree

2. It is very possible that I will look for a new job next year.

1. Strongly Disagree

2. Disagree

3. Moderately Disagree

4. Neither Disagree nor Agree

5. Moderately Agree

6. Agree

7. Strongly Agree

3. Recently, I often think of changing my current job.

1. Strongly Disagree

2. Disagree

3. Moderately Disagree

4. Neither Disagree nor Agree

5. Moderately Agree

6. Agree

7. Strongly Agree

\section{Career Commitment}

1. If I had all the money I needed without working, I would probably still continue to work in nursing.

1. Strongly Disagree

2. Disagree

3. Moderately Disagree

4. Neither Disagree nor Agree

5. Moderately Agree

6. Agree

7. Strongly Agree

2. I like my nursing career too much to give it up.

1. Strongly Disagree

2. Disagree

3. Moderately Disagree 
4. Neither Disagree nor Agree

5. Moderately Agree

6. Agree

7. Strongly Agree

3. Nursing is the ideal profession for a life's work.

1. Strongly Disagree

2. Disagree

3. Moderately Disagree

4. Neither Disagree nor Agree

5. Moderately Agree

6. Agree

7. Strongly Agree

4. I definitely want a career for myself in nursing.

1. Strongly Disagree

2. Disagree

3. Moderately Disagree

4. Neither Disagree nor Agree

5. Moderately Agree

6. Agree

7. Strongly Agree 